\title{
THE CONTINENTAL SHELF IN THE POLAR REGIONS: COLD WAR OR BLACK-LETTER LAW?*
}

\author{
Alex G. Oude Elferink**
}

1. Introduction

2. Article 76 - Background, content and operationalization

3. Specific legal frameworks in the polar regions

3.1 The Arctic

3.2 Antarctica

4. The implementation of Article 76 in the Arctic

4.1 Regional aspects

4.2 The establishment of the outer limits of the continental shelf by individual states

4.2.1 The Russian Federation

4.2.2 Norway

4.2.3 Canada, Denmark and the United States

5. The implementation of Article 76 in Antarctica

5.1 Article 76 of the Convention and the Antarctic Treaty: Maintaining constructive ambiguity

5.2 The establishment of the outer limits of the continental shelf by individual states

5.2.1 The submissions by claimant states and the reactions of other states

5.2.2 Substantive issues in the submissions on Antarctica by Argentina, Australia and Norway

* C A.G. Oude Elferink, 2010. The present article is a revised and updated version of the paper 'Het continentale plat in de poolgebieden: Koude oorlog of triomf van het recht?', published in 137 Mededelingen van de Nederlandse Vereniging voor Internationaal Recht (The Hague, T.M.C. Asser Press, November 2009) pp. 1-48. I would like to thank the board of the Netherlands Society of International Law for offering the opportunity to present that paper at the Annual Meeting of the Society on 6 November 2009. I would also like to thank the participants at that meeting for their criticism and stimulating discussions, which have assisted me in preparing the present article.

** Senior lecturer, Netherlands Institute for the Law of the Sea, School of Law, Utrecht University. 


\title{
5.2.3 The continental shelf of subantarctic islands and the Antarctic Treaty
}

\author{
6. Conclusions \\ Abstract
}

1.

INTRODUCTION

In the last couple of years there has been an increasing interest in the regime of the polar regions and in particular in that of the Arctic. Reports in the press suggest that there is a 'new race for the Arctic' or that a new 'cold war' is threatening. ${ }^{1}$ At the same time, the impression is created that international law at most has a limited role to play in the matter. ${ }^{2}$ The attention of the media for the Arctic to a large extent has been spurred by the fact that the Arctic coastal states are involved in the implementation of Article 76 of the United Nations Convention on the Law of the Sea. ${ }^{3}$

1. See for example, E. Posner, 'The New Race for the Arctic', The Wall Street Journal, 3 August 2007, p. A8.

2. The article cited in the preceding footnote for example observes: 'Power, not international law, will settle the issue. Indeed, international law recognizes this fact by making title dependent on a nation's ability to exert control over an area.'

3. 1833 UNTS p. 396. Adopted on 10 December 1982; entry into force 16 November 1994 . Hereinafter LOSC or Convention. Art. 76 (definition of the continental shelf) of the Convention, which is further considered in section 2 of the present Article, reads as follows:

' 1 . The continental shelf of a coastal State comprises the seabed and subsoil of the submarine areas that extend beyond its territorial sea throughout the natural prolongation of its land territory to the outer edge of the continental margin, or to a distance of 200 nautical miles from the baselines from which the breadth of the territorial sea is measured where the outer edge of the continental margin does not extend up to that distance.

2. The continental shelf of a coastal State shall not extend beyond the limits provided for in paragraphs 4 to 6 .

3. The continental margin comprises the submerged prolongation of the land mass of the coastal State, and consists of the seabed and subsoil of the shelf, the slope and the rise. It does not include the deep ocean floor with its oceanic ridges or the subsoil thereof.

4. (a) For the purposes of this Convention, the coastal State shall establish the outer edge of the continental margin wherever the margin extends beyond 200 nautical miles from the baselines from which the breadth of the territorial sea is measured, by either: (i) a line delineated in accordance with paragraph 7 by reference to the outermost fixed points at each of which the thickness of sedimentary rocks is at least 1 per cent of the shortest distance from such point to the foot of the continental slope; or (ii) a line delineated in accordance with paragraph 7 by reference to fixed points not more than 60 nautical miles from the foot of the continental slope. (b) In the absence of evidence to the contrary, the foot of the continental slope shall be determined as the point of maximum change in the gradient at its base. 5. The fixed points comprising the line of the outer limits of the continental shelf on the seabed, drawn in accordance with paragraph 4 (a)(i) and (ii), either shall not exceed 350 nautical miles from the baselines from which the breadth of the territorial sea is measured or shall not exceed 100 nautical miles from the 2,500 metre isobath, which is a line connecting the depth of 2,500 metres. 
In the continental shelf, the coastal state has, among other things, rights in respect of the exploitation of its natural resources. ${ }^{4}$ Article 76 provides that all coastal states are entitled to a continental shelf of 200 nautical miles. Article 76 further provides that the continental shelf extends beyond 200 nautical miles if the outer edge of the continental margin extends beyond that distance. The outer edge of the continental margin, which in certain cases may extend for hundreds of nautical miles beyond the 200-nautical-mile limit, is the area in which there is a transition from continental crust and sediments to oceanic crust. Natural resources like oil and natural gas are located inside the continental margin, but not beyond.

If the continental margin of a coastal state extends beyond 200 nautical miles, the coastal state is required to establish the outer limit of the continental shelf in accordance with the provisions of Article 76 of the Convention. The complex formulae of Article 76 in the first place require a coastal state to gather data concerning the geology and geomorphology of the continental margin. These research activities of the coastal states in the Arctic attracted the attention of the media. The planting of the Russian flag on the ocean floor at the geographical North Pole in June 2007 led to a peak in the media coverage. That this concerned an act which did not create rights over the seabed, which was acknowledged by the Russian Federation, was to a large extent ignored in the media.

Climate change has also boosted interest in the continental shelf in the Arctic. It is expected that the decrease in sea ice will make the exploitation of more oil and gas deposits economically feasible. Reports on the expected oil and gas potential of the Arctic led to the suggestion that the 'race for the Arctic' was inspired by the

\footnotetext{
6. Notwithstanding the provisions of paragraph 5, on submarine ridges, the outer limit of the continental shelf shall not exceed 350 nautical miles from the baselines from which the breadth of the territorial sea is measured. This paragraph does not apply to submarine elevations that are natural components of the continental margin, such as its plateaux, rises, caps, banks and spurs.

7. The coastal State shall delineate the outer limits of its continental shelf, where that shelf extends beyond 200 nautical miles from the baselines from which the breadth of the territorial sea is measured, by straight lines not exceeding 60 nautical miles in length, connecting fixed points, defined by coordinates of latitude and longitude.

8. Information on the limits of the continental shelf beyond 200 nautical miles from the baselines from which the breadth of the territorial sea is measured shall be submitted by the coastal State to the Commission on the Limits of the Continental Shelf set up under Annex II on the basis of equitable geographical representation. The Commission shall make recommendations to coastal States on matters related to the establishment of the outer limits of their continental shelf. The limits of the shelf established by a coastal State on the basis of these recommendations shall be final and binding.

9. The coastal State shall deposit with the Secretary-General of the United Nations charts and relevant information, including geodetic data, permanently describing the outer limits of its continental shelf. The Secretary-General shall give due publicity thereto.

10. The provisions of this Article are without prejudice to the question of delimitation of the continental shelf between States with opposite or adjacent coasts.'
}

4. LOSC, Art. 77(1). 
desire to control these newly available resources. No doubt the presence of natural resources plays an important part in the expansion of coastal state jurisdiction over maritime zones. The concept of the continental shelf was originally developed because of the possibility of oil exploitation in the offshore beyond the territorial sea. However, in the case of the Arctic two qualifications to this general point are pertinent. Coastal states are engaged in establishing the outer limit of their continental shelf to implement their obligations (and rights) under the LOSC and, as will be argued in this article, are not intent on rejecting this framework to be able to claim more extensive areas. Furthermore, from a resource perspective the continental shelf beyond 200 nautical miles is the least interesting part of the Arctic. ${ }^{5}$ Most potential resources are located onshore or within the 200-nautical-mile zones of the coastal states. Exploitation further offshore in any case will also remain more difficult and more costly in the future.

The implementation of Article 76 in Antarctica has attracted much less attention than that in the Arctic. From a legal perspective this is certainly not justified. The Antarctic Treaty ${ }^{6}$ imposes obligations on its Parties in respect of territory in Antarctica, which states will have to take into account in the implementation of their obligations under the LOSC to establish the outer limit of the continental shelf.

The present article considers the implementation of Article 76 in the polar regions and to what extent the suggestion that international law has a limited role in shaping the behaviour of coastal states in the Arctic is justified. In this connection the article also attempts to establish to what extent the implementation in the polar regions differs from that in other regions. Before addressing the establishment of the outer limits of the continental shelf in the polar regions, section 2 briefly recounts the history of Article 76, its contents and provides a general overview of its implementation. Apart from coastal states, the Commission on the Limits of the Continental Shelf (CLCS or Commission) is of particular significance in this respect. The Commission, which has been established under the LOSC, has a central role to play in assessing whether the data which have been gathered by a coastal state actually prove that the outer limits proposed by that state are in accordance with Article 76 of the Convention. Section 3 provides a brief description of the legal frameworks in the polar regions which are of relevance to the implementation of Article 76. This in particular concerns the Antarctic Treaty and other instruments which have been adopted within the framework of that treaty. Sections 4 and 5 are concerned with the implementation of Article 76 in respectively the Arctic and Antarctica. The submission of the Russian Federation in 2001 in respect of the

5. See K.J. Bird et al., Circum-Arctic Resource Appraisal: Estimates of Undiscovered Oil and Gas North of the Arctic Circle (U.S. Geological Survey Fact Sheet 2008-3049) at <http://pubs.usgs.gov/ fs $/ 2008 / 3049 /$ fs $2008-3049 . p d f>$.

6. 402 UNTS p. 71. Adopted on 1 December 1959; entry into force 23 June 1961. 
Arctic and other areas, the first submission ever to the CLCS, raised a number of questions which are fundamental to the Article 76 process. This, among others, concerns the possibilities of third states to safeguard their interests and the competence of the Commission to deal with legal matters. In Antarctica, a major concern was to design a mechanism to prevent that the implementation of Article 76 would negatively impact on cooperation within the framework of the Antarctic Treaty. Sections 4 and 5 will also briefly discuss the delimitation of the continental shelf between neighbouring states. The exact extent of the continental shelf of individual states will only be known after they will have completed the procedure contained in Article 76 and - in case of an overlap with the continental shelf of a neighbouring state - have agreed on bilateral boundaries. A final section of the article pulls together the various findings of the preceding sections and offers some overarching conclusions.

There are a number of definitions of the Arctic and Antarctica. The present article employs the following definitions. In the case of the Arctic the continental shelf in the Arctic Ocean and adjacent seas, such as the Barents Sea and the Chukchi Sea, will be taken into consideration. Other sea areas, which are more distant from the Arctic Ocean proper, such as the Norwegian Sea and the Bering Sea, are not taken into account. In the case of Antarctica, the analysis will focus on the continental shelf of the territory to the south of the latitude of $60^{\circ} \mathrm{S}$. This is the northern limit of the area of application of the Antarctic Treaty. The provisions on territory contained in the Treaty are not applicable to the so-called subantarctic islands which are located north of $60^{\circ} \mathrm{S}$. The article will however take into account the continental shelf of the subantarctic islands, in cases in which it extends into the Antarctic Treaty Area, to establish the possible consequences of the implementation of Article 76 in respect of those shelf areas for the Antarctic Treaty. Figures I and II at pp. 180 and 181 of this article show respectively the Arctic and Antarctica and provide an overview of the current state of implementation of Article 76 in these regions.

\section{ARTICLE 76 - BACKGROUND, CONTENT AND OPERATIONALIZATION}

The LOSC in general is considered to be the overarching legal framework for all ocean uses. This also concerns the regime of the continental shelf. The latter regime was first elaborated in the 1950s. In 1958, the United Nations Conference on the Law of the Sea, which was held in Geneva, reached agreement on four conventions on the law of the sea, one of which was the Convention on the continental shelf. ${ }^{7}$ This Convention has been successful in elaborating the substantive regime

7. 499 UNTS p. 311. Adopted on 29 April 1958; entry into force 10 June 1964. 
of the continental shelf. That regime in large part is identical to the regime contained in Part VI of the LOSC, which is concerned with the continental shelf.

The Convention on the continental shelf did not succeed in providing an unequivocal definition of the outer limit of the continental shelf. Article 1 of the Convention provides that the continental shelf, which comprises the seabed and subsoil of the submarine areas adjacent to the coast but beyond the area of the territorial sea, extends to a depth of 200 meters or, beyond that limit, to where the depth of the superjacent waters allows the exploitation of the natural resources of those areas.

The view that the latter criterion could lead to a division of the entire ocean floor between coastal states is not justified. ${ }^{8}$ As Article 1 of the Convention on the continental shelf indicates, it is only applicable to areas adjacent to the coast. The negotiating history of Article 1 points out that the continental shelf as defined in this article extends beyond the geophysical continental shelf. ${ }^{9}$ However, that area in all likelihood does not comprise all of the seabed of continental origin. Sediments of continental origin extend to the outer edge of the continental margin, which apart from the continental shelf also comprises the continental slope and the continental rise. ${ }^{10}$ It is unlikely that the definition of the continental shelf contained in Article 1 of the Convention on the continental shelf comprises the entire continental margin. ${ }^{11}$

The mid-1960s witnessed a growing interest in the exploitation of the mineral resources of the deep seabed. It was expected that the mining of those resources might become commercially possible in the near future, and that as a consequence it would be required to create certainty about the limit of the continental shelf and

8. This view has been advanced in some publications. See e.g., the references in S. Oda, International Control of Sea Resources (Leiden, A.W. Sijthoff 1963) pp. 166-168 and in I. Brownlie, 'Recommendations on the Limits of the Continental Shelf and Related Matters: A Commentary', in L.M. Alexander, ed., National Policy Recommendations; Proceedings of the Fourth Annual Conference of the Law of the Sea Institute, June 23-June 26, 1969 (Kingston, University of Rhode Island 1970) pp. $133-158$ at p. 138, n. 20.

9. For a detailed analysis of Art. 1 of the Convention on the continental shelf see D.N. Hutchinson, 'The Seaward Limit to Continental Shelf Jurisdiction in Customary International Law', 56 BYIL (1985) pp. 111-184 and B.H. Oxman, 'The Preparation of Article 1 of the Convention on the Continental Shelf', 3 Journal of Maritime Law and Commerce (1972) pp. 245-305, 445-472 and 683-723.

10. This schematic definition of the continental margin has been included in para. 3 of Art. 76 of the LOSC. In reality, there are often much more complex situations than are suggested by this schematic representation. A reflection of this complexity is for instance to be found in Art. 76(6) of the Convention and the intricate questions of interpretation raised by that paragraph (see also infra).

11. Hutchinson concludes that Art. 1 of the Convention by the beginning of the 1970s became part of general customary law (Hutchinson, supra n. 9, at p. 183) and that in the first half of the 1980s no rule of customary law had developed validating erga omnes claims over the continental margin beyond 200 nautical miles to the furthest edge of the continental rise (ibid., p. 184). Oxman expresses doubt as to whether the continental shelf concept contained in the Convention on the Continental Shelf covered all of the continental slope (Oxman, supra n. 9, at pp. 719-720). 
the deep seabed. Certain states proposed to allow the outer limit of the continental shelf to coincide with the newly proposed zone of 200 nautical miles, in which coastal states would also have rights over the waters superjacent to the shelf, or to abandon the continental shelf as a legal concept, instead incorporating the rights over the seabed in the regime of the 200-nautical-mile zone. These proposals were not acceptable to states with a broad continental shelf, who argued that they had acquired rights beyond 200 nautical miles. This group comprised a number of influential states, including Australia, Canada and the United States. ${ }^{12}$ During the third United Nations Conference on the Law of the Sea (1973-1982) (UNCLOS III), this group of 'margineers', from the term continental margin, was influential. Other states at the Conference tried to limit an uncontrolled extension of the sovereign rights by coastal states beyond the generally accepted limit of 200 nautical miles. ${ }^{13}$ As a consequence the outcome of the negotiations at UNCLOS III, contained in Article 76 of the Convention, is a complex compromise, which among other things employs geomorphological, geological and mathematical definitions, and provides for the establishment of the Commission on the limits of the continental shelf, which is to issue recommendations to coastal states on the delineation of the outer limits of their continental shelf.

Article 76(1) defines the continental shelf as the natural prolongation of the land territory of the coastal state to the outer edge of the continental margin, or to a distance of 200 nautical miles from the baseline, where the outer edge of the continental margin does not extend up to that distance. The subsequent paragraphs of Article 76 contain specific criteria to establish the outer edge of the continental margin beyond 200 nautical miles. The outer edge of the margin defined in accordance with Article 76 is the outer limit of the continental shelf beyond 200 nautical miles. The formulae of Article 76 imply that this outer limit in certain instances may be located beyond and in other instances within the geophysical margin.

To establish the outer limits of the continental shelf beyond 200 nautical miles a coastal state first of all has to determine the foot of the continental slope. Article 76(4)(b) provides that the foot of the continental slope, in the absence of evidence to the contrary, shall be determined as the point of maximum change in the gradient at its base. From these points at the foot of the slope a coastal state can then determine fixed points to define the outer limit of the continental shelf (Art. 76(4)(a)). The coastal in this connection can employ two formulae. A fixed point in any case

12. For a brief overview of the main arguments of these states see A.G. Oude Elferink, 'Article 76 of the LOSC on the Definition of the Continental Shelf: Questions concerning its Interpretation from a Legal Perspective', 21 International Journal for Marine and Coastal Law (2006) pp. 269-285 at pp. 271-274.

13. For the negotiation of Art. 76 see, for example, E.L. Miles, Global Ocean Politics; The Decision Process at the Third United Nations Conference on the Law of the Sea 1973-1982 (The Hague, Martinus Nijhoff 1998) passim. 
can be established at a distance of 60 nautical miles from a point along the foot of the continental slope. If the sedimentary rocks of the continental margin have a certain thickness, fixed points can be located beyond that distance of 60 nautical miles. A specific point may be used if the thickness of sedimentary rocks is at least 1 per cent of the shortest distance from such a point to the foot of the slope. This second formula was included in Article 76 because it was considered to ensure that most exploitable hydrocarbon resources would be located in the continental shelf.

Fixed points which have been established in accordance with Article 76(4) may only be employed to define the outer limit of the continental shelf if they meet a number of additional criteria. First of all, these points shall not exceed: a) 350 nautical miles from the baselines from which the breadth of the territorial sea is measured; or b) 100 nautical miles from the 2,500 meter isobath (Art. 76(5)). The latter criterion does not apply to submarine ridges. In this case only the criterion of 350 nautical miles is applicable (Art. 76(6)). However, the exception of Article $76(6)$ is not applicable to 'submarine elevations that are natural components of the continental margin, such as its plateaux, rises, caps, banks and spurs' (Art. 76(6)).

It has been suggested that the first sentence of paragraph 76(6) on submarine ridges 'had no known, and certainly, no agreed, application. It might arguably apply to a submarine ridge that was neither essentially oceanic nor essentially continental in origin. But it did not and does not apply to any known ridge. ${ }^{14}$ Whether the latter is the case is, to say the least, doubtful. Iceland applied Article 76(6) to define the outer limit of its continental shelf on the Reykjanes Ridge just after the adoption of the Convention. ${ }^{15}$ The CLCS in a number of cases has issued recommendations to coastal states, which are concerned with an outer limit at 350 nautical miles on the basis of the first sentence of Article 76(6). This is not to say that the interpretation and application of Article 76(6) is an easy task. The Commission in its Scientific and Technical Guidelines has indicated which criteria it will apply to distinguish between submarine ridges and submarine elevations. The Commission has concluded:

'that in cases of ridges its view shall be based on such scientific and legal considerations as natural prolongation of land territory and land mass, morphology of ridges and their relation to the continental margin $[\ldots]$ and continuity of ridges.

As it is difficult to define the details concerning various conditions, the Commission feels it appropriate that the issue of ridges be examined on a case-by-case basis. ${ }^{16}$

14. United States of America: Comments on the Provisional Scientific and Technical Guidelines of the Commission on the Limits of the Continental Shelf (CLCS/L.6) (CLCS/CRP.15 of 28 April 1999) para. 35.

15. See Regulation No. 196 of 9 May 1986 concerning the delimitation of the continental shelf to the West, South and East (Law of the Sea Bulletin No. 8, pp. 10-13). See also infra the text at n. 22.

16. Scientific and Technical Guidelines of the Commission on the Limits of the Continental Shelf (CLCS/11 of 13 May 1999) paras. 7.2.10 en 7.2.11. 
As regards the classification of submarine elevations, the Commission has indicated that the criterion mentioned in Article 76(6) that they have to be a natural component of the continental margin implies that it is relevant to consider the processes that form the continental margins and how continents grow. ${ }^{17}$

Under Article 76 it is first of all relevant, and the above is accordance with that consideration, both for submarine ridges and submarine elevations to demonstrate that there is a natural prolongation of the land territory of the coastal state. In both cases geological and geomorphological criteria may be relevant to this determination. The travaux préparatoires of Article 76 furthermore indicate that the provision concerning submarine ridges was among other things intended to prevent that islands situated on oceanic ridges would have a continental shelf beyond 350 nautical miles. ${ }^{18}$ This latter aspect of Article 76(6) seems to have been lost from sight in the elaboration of Article 76 in the Scientific and Technical Guidelines of the Commission. Under the rules of treaty interpretation contained in the Vienna Convention on the law of treaties, recourse can be had, among others, to the travaux préparatoires of a treaty if the general rule of treaty interpretation leaves the meaning of terms ambiguous or obscure. ${ }^{19}$ The Commission, instead of having had recourse to the travaux, seems to have constructed its meaning of Article 76(6) by reference to the scientific understanding of the terms contained in Article $76 .^{20}$ This is not a matter of legal dogmatism. The two approaches may in practice lead to different outcomes. From the executive summary of Iceland's submission to the CLCS on 29 April 2009 it appears that Iceland no longer maintains the position that the first sentence of Article 76(6) is applicable to the Reykjanes Ridge. ${ }^{21}$ The outer limit of Iceland's continental shelf on the Reykjanes Ridge is well beyond the 350-nautical-mile limit. ${ }^{22}$ The shift in the position of Iceland in respect of Article 76(6) mentioned previously may be (partly) due to the way in which the Commission has dealt with the matter of submarine ridges in considering submissions.

17. Ibid., para. 7.3.1.

18. See further Committee on legal issues of the outer continental shelf, 'Second Report' in Report of the Seventy-Second Conference; Toronto 2006 (London, International Law Association 2006) pp. 215-249 at pp. 219-222.

19. Adopted on 23 May 1969; entry into force on 27 January 1980 (1155 UNTS 331) Art. 32.

20. Terms in Art. 76 do not necessarily have the meaning they are generally understood to have in the earth sciences. A case in point is the use in Art. 76 of the term continental shelf, which coincides with the continental margin and not the shelf as understood in the earth sciences.

21. See supra the text at $\mathrm{n}$. 15 for Iceland's earlier position.

22. The Icelandic Continental Shelf Partial Submission to the Commission on the Limits of the Continental Shelf pursuant to Article 76, paragraph 8 of the United Nations Convention on the Law of the Sea in respect of the Ægir Basin area and Reykjanes Ridge, Part I Executive Summary, at $<\mathrm{http}: / /$ www.un.org/Depts/los/clcs_new/clcs_home.htm>; documents of the Commission (identified by the acronym CLCS) and information concerning the submissions of other states are also available on this website). 
Fixed points which meet the conditions contained in Article 76(4) to (6) may be employed to define the outer limit of the continental shelf beyond 200 nautical miles. The straight lines connecting these points may as a maximum measure 60 nautical miles (Art. 76(7)). Before establishing the outer limit on the basis of these criteria, a coastal state is required to submit information concerning those limits to the CLCS within 10 years of having become a Party to the Convention (LOSC, Annex II, Art. 4). During the 11th Meeting of States Parties to the Convention in 2001, the decision was taken that for states, which had become a Party to the Convention before 13 May 1999, the period of 10 years had started to run on that date. $^{23}$

The limits of the continental shelf established by the coastal state on the basis of the recommendations of the Commission are final and binding (Art. 76(8)). In the case of disagreement with the recommendations of the Commission, the Convention requires a coastal state to make a new or revised submission within a reasonable time (LOSC, Annex II, Art. 8).

The Commission is charged with establishing whether data and other material submitted by a coastal state demonstrate that the proposed outer limit lines are in accordance with Article 76 (LOSC, Annex II, Art. 3). The Commission, which consists of 21 members, is primarily required in that connection to consider the scientific and technical aspects of the implementation of Article 76 by coastal states (LOSC, Annex II, Art. 3). The Convention requires that members of the Commission are experts in the field of geology, geophysics or hydrography (LOSC, Annex II , Art. 2(1)). Legal expertise is lacking from this list. However, as is witnessed by the practice of the Commission, it will inevitably also be faced with legal matters. ${ }^{24}$ An important issue in this respect, also for the polar regions, is constituted by questions concerning territory and the delimitation of maritime boundaries between neighbouring states. Paragraph 10 of Article 76 establishes that the provisions of Article 76 are without prejudice to the delimitation of the continental shelf between neighbouring states and Article 9 of Annex II to the Convention provides that the actions of the Commission shall not prejudice matters relating to the delimitation of boundaries between neighbouring states.

23. Decision regarding the Date of Commencement of the Ten-Year Period for Making Submissions to the Commission on the Limits of the Continental Shelf Set Out in Article 4 of Annex II to the United Nations Convention on the Law of the Sea (SPLOS/72 of 29 May 2001). For the reasons for this decision see infra.

24. For the competence of the Commission to deal with legal questions see for instance Committee on legal issues of the outer continental shelf, supra n. 18, at pp. 226-229; L.D.M. Nelson, 'The Settlement of Disputes Arising from Conflicting Outer Continental Shelf Claims', 24 International Journal of Marine and Coastal Law (2009) pp. 409-422. 
The Commission has further implemented the requirement of Article 9 of Annex II through its Rules of Procedure. ${ }^{25}$ Rule 46 provides for a special procedure for handling submissions by coastal states in relation to which there is a dispute concerning the delimitation of the continental shelf or other maritime or territorial disputes. This special procedure, which is contained in Annex I to the Rules of Procedure, allows a state to limit its submission to a specific area or to make a submission together with neighbouring states. Annex I furthermore provides that the Commission, in a case in which a dispute exists, will only consider the submission of a coastal state with the prior consent of all states that are parties to the dispute. To offer other states the possibility to establish if there exists a dispute related to the submission of a coastal state, the latter is required to draw up an executive summary of the submission, which is published after the submission has been made. ${ }^{26}$ The remaining part of a submission is not made public.

The Commission was first established in 1997. After a slow start - only in December 2001 was the first submission made by the Russian Federation, which was followed by Brazil in May 2004 - 51 submissions have now been made to the CLCS, involving 44 states. ${ }^{27}$ In addition, a large number of states have submitted preliminary information. Apart from a number of states, which have also made submissions, this concerns another 29 states. The submission of preliminary information was not envisaged by the Convention, but was created by a decision of the 18th Meeting of States Parties to the Convention in June 2008. ${ }^{28}$ This procedure is in particular intended to address the difficulties of developing states in meeting the 10 -year time limit for making a submission. The decision of the Meeting established that states comply with this requirement by submitting preliminary information. $^{29}$

It has been suggested that Rule 46 and Annex I to the Rules of Procedure of the Commission and the decisions of the Meeting of States Parties concerning the time limit for making submissions to the Commission cannot lead to changing the obligations concerning the submission of information as contained in the Convention. ${ }^{30}$

25. Rules of Procedure of the Commission on the Limits of the Continental Shelf (the current version of the Rules of Procedure is contained in CLCS/40 Rev.1 of 17 April 2008).

26. Rules of Procedure, Rule 50.

27. A number of states have made joint submissions or separate submissions for different parts of their continental shelf.

28. The decision is contained in SPLOS/183 of 20 June 2008, at $<$ http://daccessdds.un.org/doc/ UNDOC/GEN/N08/398/76/PDF/N0839876.pdf?OpenElement>.

29. For an analysis of the decision see A.G. Oude Elferink, 'The Time Limit for Making Submissions to the Commission on the Limits of the Continental Shelf - the Current State of Affairs', 23 International Journal of Marine and Coastal Law (2008) pp. 769-778.

30. See B. Kunoy, 'The 10 Year Time Frame to Disputed Areas', 40 Ocean Development and International Law (2009) pp. 131-145. 
However, no arguments supporting this opinion seem to exist. The Meeting of States Parties took note of a draft of Rule 46 and Annex I to the Rules of Procedure and no observations to that effect were made. The decisions of the Meeting were adopted by consensus. A large number of States Parties based themselves on these instruments in implementing Article 76 of the Convention. Both States Parties and states that are not Party to the Convention have reacted to the submission of information by coastal states. That practice indicates that it is generally accepted that states have employed the possibilities offered by Annex I and the decisions. ${ }^{31}$

A submission by a coastal state is in principle first considered by a subcommission of the CLCS, which is composed of seven members. The coastal state which has made the submission is allowed to participate in the relevant proceedings without a right to vote (LOSC, Annex II, Art. 5). The subcommission submits its recommendations to the Commission. Approval by the full Commission requires a majority of two thirds of the Commission members present and voting (LOSC, Annex II, Art. 6).

As far as can be established all states, which were required to submit information in accordance with Article 76, have done so by making a submission or submitting preliminary information. For a limited number of states, for which the Convention entered into force less than 10 years ago, or which have not yet become a Party to the Convention, it is possible to make a submission at a later date. This is the case for, among others, the Arctic states of Canada, Denmark and the United States. ${ }^{32}$ Canada and Denmark became Party to the Convention in respectively December 2003 and December 2004. The United States is not a Party to the Convention. States which are not a Party to the Convention are not entitled to employ the procedure for establishing the outer limits of the continental shelf involving the Commission. ${ }^{33}$ To what extent the substantive provisions of Article 76 reflect customary law is not completely clear. It can for instance be noted that by far the most practice in respect of Article 76 concerns States Parties to the Convention. Moreover, under the Convention Article 76 on the definition of the continental shelf is accompanied by the obligation to make payments or contributions with respect to the continental shelf beyond 200 nautical miles contained in Article 82 . The practical significance of the content of customary law is limited. Apart from the United States, almost all states with a continental shelf beyond 200 nautical miles are a Party to the Convention. ${ }^{34}$ The United States Government has observed

31. See also Oude Elferink, supra n. 29.

32. Denmark has made a submission to the Commission in respect of an area to the north of the Far Oer. Other states for which the 10-year time limit falls after 12 May 2009 are Madagascar and Bangladesh.

33. See Committee on legal issues of the outer continental shelf, supra n. 18, at pp. 239-240.

34. Ecuador, another state which is not a Party to the Convention, has also indicated that its continental shelf extends beyond 200 nautical miles. 
that accession to the Convention by the United States would offer the opportunity to employ Article 76 to clarify the extent of the continental shelf. ${ }^{35}$

It will take the CLCS a considerable time to deal with all the submissions which have been lodged thus far. It is expected that the Commission under the currently existing conditions only in a couple of decades will have dealt with the submissions which have been lodged thus far. Submissions are handled in accordance with the date of lodgment. Three of the five coastal states in the Arctic, Canada, Denmark and the United States, will consequently have to join at the end of the existing queue.

\section{SPECIFIC LEGAL FRAMEWORKS IN THE POLAR REGIONS}

\subsection{The Arctic}

From a legal perspective, the most important difference between the polar regions is no doubt the absence of territorial disputes in the Arctic, with the exception of certain small islands, whereas in Antarctica, the regional legal framework is based on the Antarctic Treaty, which envisages international cooperation in the absence of a territorial sovereign.

In the Arctic there is no regional legal framework that significantly impacts on the implementation of the rules on the establishment of maritime zones contained in the LOSC. There is, however, one matter which is specific to that region. ${ }^{36} \mathrm{Be}-$ cause of the inhospitable character of the Arctic, in particular Canada and the Russian Federation have employed so-called sector lines in connection with sovereignty claims over islands. ${ }^{37}$ Sector lines are meridians which, starting from the land boundaries of a state, run to the geographical North Pole and as a consequence encompass a sector of the Arctic. The Soviet Union and after it the Russian Federation have taken the position that sector lines are also relevant for the delimitation of maritime boundaries with neighbouring states. ${ }^{38}$ This position is also reflected in the implementation of Article 76 by the Russian Federation. ${ }^{39}$

35. See further infra.

36. The regime applicable to Norway's Svalbard archipelago moreover raises a number of specific issues in relation to the maritime zones of these islands (see further infra).

37. For further discussion see for example, D. Pharand, Canada's Arctic Waters in International Law (Cambridge, CUP 1988) pp. 1-79.

38. Canada takes the position that the meridian which constitutes the land boundary between Canada and Alaska is also the maritime boundary with the United States. In this case Canada is in particular relying on a specific interpretation of the treaty establishing the land boundary, and, in the view of Canada, also the maritime boundary.

39. See further infra. 


\subsection{Antarctica}

The Antarctic Treaty, which was adopted in 1959, provides the legal framework for international cooperation in Antarctica. Previous to the adoption of the Antarctic Treaty a number of states had made territorial claims to parts of the Antarctic continent and islands in the Southern Ocean. In the 1950s this concerned Argentina, Australia, Chile, France, New Zealand, Norway and the United Kingdom. Moreover, it was not excluded that the United States and the Soviet Union, which both had an interest in the area, would also make a formal claim to a part of Antarctica. Other states have rejected the claims to territory in the Antarctic.

The Antarctic Treaty is intended to guarantee that cooperation in Antarctica between states is possible without resulting in conflicts over the significance of this cooperation for the territorial claims to Antarctica. A central role in this respect is played by Article IV of the Treaty, which provides:

1. Nothing contained in the present Treaty shall be interpreted as:

(a) a renunciation by any Contracting Party of previously asserted rights of or claims to territorial sovereignty in Antarctica;

(b) a renunciation or diminution by any Contracting Party of any basis of claim to territorial sovereignty in Antarctica which it may have whether as a result of its activities or those of its nationals in Antarctica, or otherwise;

(c) prejudicing the position of any Contracting Party as regards its recognition or non-recognition of any other State's right of or claim or basis of claim to territorial sovereignty in Antarctica.

2. No acts or activities taking place while the present Treaty is in force shall constitute a basis for asserting, supporting or denying a claim to territorial sovereignty in Antarctica or create any rights of sovereignty in Antarctica. No new claim, or enlargement of an existing claim, to territorial sovereignty in Antarctica shall be asserted while the present Treaty is in force.

Article IV of the Antarctic Treaty has allowed states to collaborate without prejudicing their positions concerning the status of Antarctica. This approach, however, is not free from tension. States with a territorial claim seek to accomplish that their actions do not in any way weaken their claims, whereas other states aim to prevent that their actions in any way imply a recognition of these claims. This situation has been referred to as 'constructive ambiguity' and the 'bifocal approach'. This approach is reflected in treaties which have been adopted within the framework of the Antarctic Treaty and which are intended to provide a more detailed regulation for specific subject-matters. This body of treaties is also known as the Antarctic Treaty System (ATS). One of the questions which had to be answered in the negotiations of all these instruments was the status of the waters around Antarctica. 
The Antarctic Treaty only refers to the status of the high seas and does not refer explicitly to coastal state zones. ${ }^{40}$ Article IV of the Treaty is relevant to determining the significance of the Treaty for the status of the waters around Antarctica. On the one hand, it has been submitted that Article IV excludes that claimant states may establish maritime zones, certainly to the extent that those maritime zones were non-existent at the time when the Treaty entered into force in 1961. On the other hand, the view has been advanced that Article IV is concerned with territory and not with the maritime zones appurtenant to that territory. ${ }^{41}$

The first treaty with a maritime dimension which was negotiated within the framework of the Antarctic Treaty is the Convention on the Conservation of Antarctic Seals (CCAS) of 1 June $1972 .{ }^{42}$ The CCAS does not contain provisions specifically dealing with the maritime zones of Antarctica, but reaffirms the provisions of the Antarctica Treaty. ${ }^{43}$ At the time when the CCAS was negotiated before UNCLOS III took place - a large number of the participating states did not yet agree with the extension of coastal state jurisdiction as included in the LOSC, which was the result of UNCLOS III. This is probably part of the explanation as to why the CCAS, contrary to later treaties adopted in the framework of the ATS, does not contain provisions specifically dealing with maritime zones. A number of claimant states has indicated that the CCAS is without prejudice to the rights of contracting parties in respect of maritime zones. ${ }^{44}$

At the end of the 1970s, the question of the status of the maritime zones of Antarctica had to be considered once more in the framework of negotiations on a

40. The reference to the high seas in Art. VI of the Treaty has been used to argue that all the waters adjacent to Antarctica have the status of high seas. Another interpretation is that Art. VI is only intended to reaffirm that the Antarctic Treaty is without prejudice to the regime of the high seas, without determining the extent of the high seas. For the interpretation of Art. VI see for instance, M.T. Infante, 'The Continental Shelf of Antarctica: Legal Implications for a Regime on Mineral Resources', in F. Orrego Vicuña, ed., Antarctic Resource Policy; Scientific, Legal and Political Issues (Cambridge, CUP 1983) pp. 253-264; R. Lefeber, 'The Exercise of Jurisdiction in the Antarctic Region and the Changing Structure of International Law: The International Community and International Interests', 21 NYIL (1990) pp. 81-137 at p. 129; T. Scovazzi, 'The Antarctic Treaty System and the New Law of the Sea: Selected Questions', in F. Francioni and T. Scovazzi, eds., International Law for Antarctica (The Hague, Kluwer Law International 1997) pp. 377-394 at pp. 386-387; A. van der Essen, 'The Arctic and Antarctic Regions', in R. Dupuy and D. Vignes, eds., A New Handbook on the Law of the Sea (Dordrecht, Martinus Nijhoff 1991) pp. 525-560, at pp. 549-550.

41. For the interpretation of Art. IV see for instance, Infante supra n. 40, at pp. 254-256; Scovazzi, supra n. 40, at pp. 383-385; G.D. Triggs, 'The Antarctic Treaty System: Some Jurisdictional Problems', in G.D. Triggs, ed., The Antarctic Treaty Regime; Law, Environment and Resources (Cambridge, CUP 1987) pp. 90-91; Van der Essen, supra n. 40, at pp. 549-550.

42. 1080 UNTS p. 175. Entry into force 11 March 1978.

43. CCAS, Art. 1(1).

44. See F. Orrego Vicuña, 'The Law of the Sea and the Antarctic Treaty System: New Approaches to Offshore Jurisdiction', in C.C. Joyner and S.K. Chopra, eds., The Antarctic Legal Regime (Dordrecht, Martinus Nijhoff 1988) pp. 97-127 at pp. 106-107. 
treaty on the living resources in the seas surrounding Antarctica. At that point in time there existed an almost universal agreement that coastal states have the right to establish a 200-nautical-mile zone to manage and conserve living resources. ${ }^{45}$ This development is reflected in the Convention on the Conservation of Antarctic Marine Living Resources (CCAMLR). ${ }^{46}$ Apart from providing that Articles IV and VI of the Antarctic Treaty are applicable to the Parties to CCAMLR, ${ }^{47}$ the Convention also establishes that it is without prejudice to the positions of the Parties with respect to coastal state jurisdiction. ${ }^{48}$

The international acceptance of the 200-nautical-mile zone required the negotiators of CCAMLR to also take into account the status of the maritime zones of a number of islands located to the north of the area of application of the Antarctic Treaty, which is limited by the latitude of $60^{\circ} \mathrm{S}$. Contrary to territory to the south of that latitude, the existence of sovereignty over these islands, also known as the subantarctic islands, is generally recognized. The 200-nautical-mile zone of these islands - Bouvet (Norway), the Crozet Islands and the Kerguelen (France), Heard Island and the McDonald Islands (Australia), the Prince Edward Islands (South Africa) and South Georgia and the South Sandwich Islands (under the authority of the United Kingdom; sovereignty is also claimed by Argentina) - overlaps with the area of application of CCAMLR. ${ }^{49}$ The status of the maritime zones of the subantarctic islands is addressed by Article IV of CCAMLR. Furthermore, the chairman of the conference at which the Convention was adopted issued a statement on the applicability of CCAMLR to the waters around the Crozet Islands and the Kerguelen,

45. A large number of states at the end of the 1970s had established an exclusive economic zone, modelled on the provision of what later became Part V of the LOSC. Other states, which did not want to anticipate the outcome of UNCLOS III, established a 200-nautical-mile fishing zone.

46. (1980) 19 ILM p. 841. Adopted on 20 May 1980; entry into force 7 April 1982.

47. CCAMLR, Art. IV(1).

48. Art. IV(2) of CCAMLR provides:

'2. Nothing in this Convention and no acts or activities taking place while the present Convention is in force shall:

(a) constitute a basis for asserting, supporting or denying a claim to territorial sovereignty in the Antarctic Treaty area or create any rights of sovereignty in the Antarctic Treaty area;

(b) be interpreted as a renunciation or diminution by any Contracting Party of, or as prejudicing, any right or claim or basis of claim to exercise coastal state jurisdiction under international law within the area to which this Convent

ion applies;

(c) be interpreted as prejudicing the position of any Contracting Party as regards its recognition or non-recognition of any such right, claim or basis of claim;

(d) affect the provision of Article IV, paragraph 2, of the Antarctic Treaty that no new claim, or enlargement of an existing claim, to territorial sovereignty in Antarctica shall be asserted while the Antarctic Treaty is in force.'

49. This overlap is mostly explained by the fact that the area of application of CCAMLR extends north of $60^{\circ} \mathrm{S}$, which is the northern boundary of the Antarctic Treaty (see CCAMLR, Art. I). 
for which France had already instituted a 200-nautical-mile zone. The statement assigns France a considerable margin of appreciation in the establishment and enforcement of conservation measures in the maritime zones of the islands. ${ }^{50}$ The statement also provides:

5. The understandings, set forth in paragraphs 1 to 4 above, regarding the application of the Convention to waters adjacent to the islands of Kerguelen and Crozet, also apply to waters adjacent to the islands within the area to which this Convention applies over which the existence of State sovereignty is recognised by all Contracting Parties. No objection to the statement was made. ${ }^{51}$

The South Sandwich Islands are the only subantarctic islands whose 200-nauticalmile zone extends south of $60^{\circ} \mathrm{S}$ into the area of application of the Antarctic Treaty. The position of the United Kingdom indicates that a distinction is made between that area and other parts of the maritime zones of the islands. ${ }^{52}$

The Convention on the Regulation of Antarctic Mineral Resource Activities (CRAMRA), which was adopted in 1988, addresses the definition of the continental shelf in Antarctica. ${ }^{53}$ For that reason the Convention is of interest for the present discussion, even though it is excluded that it will enter into force in the near future. The growing resistance against mining activities in Antarctica after the negotiation of CRAMRA led to the adoption of the Protocol on Environmental Protection to the Antarctic Treaty in $1991 .^{54}$ The Protocol has resulted in a moratorium on mining until 2048. ${ }^{55}$ The Protocol, like the Antarctic Treaty, is applicable to the area south of $60^{\circ} \mathrm{S}$. Under the Protocol there is no need to arrive at a more precise definition of the continental shelf of Antarctic territories in the framework of the ATS. To the contrary, this would have been required had CRAMRA entered into force.

The area of application of CRAMRA is defined in its Article 5:

50. See also E. Molenaar, 'CCAMLR and Southern Ocean fisheries', 16 International Journal of Marine and Coastal Law (2001) pp. 465-499 at pp. 479-480.

51. Statement by the Chairman of the Conference on the Conservation of Antarctic Marine Living Resources (19 May 1980), at <http://www.ccamlr.org/pu/e/e pubs/bd/pt1.pdf>.

52. See Commission for the Conservation of Antarctic Marine Living Resources, Report of the Eighteenth Meeting of the Commission (Hobart, Australia 25 October - 5 November 1999); CCAMLRXVIII, p. 52, para. 13.4. Argentina, which also claims sovereignty over the islands, has taken the position that the Statement is not applicable to the subantarctic islands, in respect of which sovereignty is disputed (see ibid., pp. 52-53, para. 13.5 and the references contained in the paragraph).

53. (1988) 27 ILM. Adopted on 2 June 1988; not yet entered into force.

54. (1991) 30 ILM. Adopted on 4 October 1991; entry into force 15 January 1998.

55. See CRAMRA, Art. 7. 
1. This Convention shall, subject to paragraphs 2, 3 and 4 below, apply to the Antarctic Treaty area.

2. Without prejudice to the responsibilities of the Antarctic Treaty Consultative Parties under the Antarctic Treaty and measures pursuant to it, the Parties agree that this Convention shall regulate Antarctic mineral resource activities which take place on the continent of Antarctica and all Antarctic islands, including all ice shelves, south of 60 degrees south latitude and in the seabed and subsoil of adjacent offshore areas up to the deep seabed.

3. For the purposes of this Convention 'deep seabed' means the seabed and subsoil beyond the geographic extent of the continental shelf as the term continental shelf is defined in accordance with international law.

The Final Act of the meeting at which CRAMRA was adopted contains two interpretative statements in respect of Article $5 .{ }^{56}$ First of all, the continental shelf of the subantarctic islands is, in similar fashion to the approach of CCAMLR, excluded from the scope of application of CRAMRA: 'the Convention does not extend to any continental shelf appurtenant in accordance with international law to islands situated north of $60^{\circ}$ south latitude'. The continental shelf beyond 200 nautical miles of certain subantarctic islands extends into the area south of $60^{\circ} \mathrm{S}$. This interpretative statement implies that CRAMRA is without prejudice to the establishment of the outer limit of that continental shelf in accordance with international law.

Secondly, the Final Act provides that the geographic extent of the continental shelf as referred to in Article 5 of CRAMRA 'would be determined by reference to all the criteria and the rules embodied in paragraphs 1 to 7 of the United Nations Convention on the Law of the Sea'. The Final Act also provides that it is without prejudice to the legal position of any Party under the Antarctic Treaty.

Article 5 of CRAMRA and the Final Act on the one hand imply that the definition of the continental shelf in that Convention is detached from the existence of a coastal state and the normal procedure for the establishment of the outer limit of the continental shelf. Article 5 refers to the geographic extent of the continental shelf as the term is defined in accordance with international law and the area of application of CRAMRA is defined negatively in Article 5(3) by referring to the area to which the Convention is not applicable. The Final Act refers to the determination of the geographic extent of the continental shelf by reference to paragraphs 1 to 7 of Article 76 of the LOSC. Paragraphs 8 to 10, which envisage the submission of information by the coastal state to the CLCS and the final and binding nature of the outer limit of the continental shelf established by the coastal state on the basis of the recommendations of the Commission and that Article 76 is without

56. For the text of these statements see the Final Act of the Fourth Special Antarctic Treaty Consultative Meeting on Antarctic Mineral Resources ((1988) 27 ILM pp. 865-867 at p. 866). 
prejudice to the delimitation between neighbouring states, are not referred to in the interpretative statement of the Final Act. ${ }^{57}$

On the other hand, Article 5 and the Final Act implied that following the entry into force of CRAMRA the area of application of the Convention would have been determined in accordance with the generally applicable substantive rules contained in Article 76 of the LOSC. CRAMRA and the Final Act do not address how Article 5 would have to be implemented after the entry into force of the Convention. In that case a number of questions would have presented themselves. The establishment of the outer limits of the continental shelf beyond 200 nautical miles involves significant costs, which will normally be borne by the coastal state. It is questionable whether that approach was also available in Antarctica. On the one hand, claimant states might have considered that they should not be solely responsible for the costs of implementation. On the other hand, non-claimant states might have considered implementation by the claimant states undesirable. Secondly, under Article 76 it is possible to define the outer limit beyond 200 nautical miles, even on the basis of the same data, by reference to different fixed points. The agreement on the continental shelf in the framework of CRAMRA did not specify who would have been responsible for making these choices. Thirdly, the exclusion of paragraph 8 of Article 76 would have implied that for the establishment of the area of application of CRAMRA the procedure involving the CLCS, which constituted an essential element of the compromise contained in Article 76, would have been excluded. The exclusion of the CLCS might have made the outer limits established in the implementation of CRAMRA unacceptable to third states or there might have been a risk that it would have led to calls for a general relaxation of the constraints imposed on coastal states. These issues suggest, on balance, that claimant states might have argued, if CRAMRA would have entered into force, that they would have been required to implement Article 76 in its entirety for their Antarctic territories.

\section{THE IMPLEMENTATION OF ARTICLE 76 IN THE ARCTIC ${ }^{58}$}

\subsection{Regional aspects}

Coverage of recent developments in the Arctic regularly gives the impression that the law is completely irrelevant and that the continental shelf will be divided on the

57. See also Lefeber, supra n. 40, at pp. 130-131.

58. For other discussions on the implementation of Art. 76 in the Arctic see for example, T. Koivurova, 'Do the Continental Shelf Developments Challenge the Polar Regimes?', 1 The Year- 
basis of power politics. ${ }^{59}$ This trend reached its zenith after the flag of the Russian Federation was planted on the seabed at the geographical North Pole. Politicians also contributed to creating the image that law was of limited significance. For instance, Prime Minister Harper of Canada declared on 9 July 2007: 'Canada has a choice when it comes to defending our sovereignty over the Arctic. We either use it or lose it'. ${ }^{60}$

There can be little doubt that the tensions created by this coverage of Arctic developments contributed to the adoption of the Ilulissat Declaration by the coastal states of the Arctic Ocean (Canada, Denmark, Norway, the Russian Federation and the United States) on 28 May $2008 .{ }^{61}$ Informal discussions on this matter had already taken place between the five states at the invitation of Norway in October 2007. At that time the importance of the law of sea for the establishment of the outer limits of the continental shelf in the Arctic Ocean had already been recognized. ${ }^{62}$

The Ilulissat Declaration emphasizes the importance of international cooperation and the role of coastal states in that cooperation. The Declaration also stresses the significance of international law:

'Notably, the law of the sea provides for important rights and obligations concerning the delineation of the outer limits of the continental shelf, the protection of the marine environment, including ice-covered areas, freedom of navigation, marine scientific research, and other uses of the sea. We remain committed to this legal framework and to the orderly settlement of any possible overlapping claims.'

As can be observed, the Declaration refers to the delineation of the outer limits of the continental shelf and the settlement of questions relating to overlapping maritime claims between neighbouring states. The Declaration does not provide explic-

book of Polar Law (2009) pp. 477-497; B. Kunoy, 'A New Arctic Conquest: the Arctic Outer Continental Margin', 76 Nordic JIL (2007) pp. 465-480; A. Proelss and T. Müller, 'The Legal Regime of the Arctic Ocean', 68 ZaöRV (2008) pp. 651-687 at pp. 661-683; T. Potts and C. Schofield, 'The Arctic', 23 International Journal of Marine and Coastal Law (2008) pp. 151-176; M. Weber, 'Defining the Outer Limits of the Continental Shelf across the Arctic Basin: The Russian Submission, States' Rights, Boundary Delimitation and Arctic Regional Cooperation', 24 International Journal of Marine and Coastal Law (2009) pp. 653-681.

59. See for instance, the article mentioned in supra $\mathrm{n} .1$.

60. 'Prime Minister Stephen Harper announces new Arctic offshore patrol ships, 9 July 2007 Esquimalt, British Columbia', at $<$ http://pm.gc.ca/eng/media.asp?id=1741>.

61. The text of the declaration is available at $<\mathrm{http}$ //arctic-council.org/filearchive/Ilulissatdeclaration.pdf $>$.

62. See The Arctic Ocean - meeting in Oslo (Press release No. 128/07 of 17 October 2007, at $<$ http://www.regjeringen.no/en/dep/ud/press/News/2007/The-Arctic-Ocean-meeting-in-Oslo.html?id=486239>. 
itly that the rules for delineating the outer limit of the continental shelf are those contained in Article 76 of the LOSC. Consequently, the Declaration does not address the exact nature of the obligations of the United States, which is not a Party to the Convention, under international law in respect of the establishment of the outer limits of its continental shelf. ${ }^{63}$ It is interesting to note that the term 'delineation' contained in the Declaration suggests an obligation to establish specific outer limit lines. The term 'delineation' is also contained in paragraph 7 of Article 76 of the LOSC.

The Ilulissat Declaration confirms that the coastal states of the Arctic Ocean take the position that the law of the sea is applicable to the area without exception. The Arctic policy of individual states also emphasizes the importance of the existing legal framework. A recent policy statement by the United States observes in this respect:

'The most effective way to achieve international recognition and legal certainty for our extended continental shelf is through the procedure available to States Parties to the UN Convention on the Law of the Sea. ${ }^{64}$

A similar emphasis on the importance of the existing legal framework is reflected in Canadian and Russian Arctic policy statements. ${ }^{65}$

Figure I, at p. 180, provides an overview of the current state of the implementation of Article 76 in the Arctic. The figure includes information on the location of the two constraint lines of Article 76(6). That information indicates that there is an area in the Central Arctic Ocean beyond both constraint lines north of Canada. ${ }^{66}$ However, current information suggests that other areas of the Central Arctic Ocean are also beyond the limits of the continental shelf. The outer limit lines of the Russian Federation and Norway indicate that there is such an area just north of their 200-nautical-mile zones. Current information on the projected outer limits of the continental shelf of Greenland indicates that this area also extends into the equidistance area of Greenland. ${ }^{67}$ As is witnessed by the discussion which follows,

63. It is uncertain whether the substantive provisions of Art. 76 reflect customary international law (see also supra).

64. National Security Presidential Directive and Homeland Security Presidential Directive (NSPD66 / HSPD-25) of 9 January 2009, section III.D.1. See also ibid., section III.D.4.

65. Canada's Northern Strategy; Our North, Our Heritage, Our Future (2009), pp. 12-13; Osnovy gosudarstvennoi politiki Rossiiskoi Federatsii v Arktike na period do 2020 goda i dal'neishuiu perspektivy (Bases of the government policy of the Russian Federation for the period up to 2020 and a further perspective), of 18 September 2008, sections I.2 en III.6.

66. A smaller area beyond both constraints, which is located at the intersection of the 350-nautical-mile lines of Denmark and the Russian Federation, is not included in Figure I.

67. See further infra section 4.2.3. 
the further implementation of Article 76 may identify further areas which are beyond the outer limit of the continental shelf in the Arctic.

\subsection{The establishment of the outer limits of the continental shelf by individual states}

\subsubsection{The Russian Federation}

In December 2001, the Russian Federation was the first state to make a submission to the CLCS. Two of the in total four areas for which the submission was made are in the Arctic. One of those areas is located in the central Arctic Ocean, the other in the Barents Sea, to the north of the mainland coasts of Norway and the Russian Federation. ${ }^{68}$ The latter area is surrounded in its totality by the 200 -nautical-mile zones of both states. This area is comparatively shallow and all of it is located within the continental margin. There can be no doubt that the entire area is part of the continental shelf of both states. As a consequence the outer limit of the continental shelf of Norway and the Russian Federation in this area will be constituted by the bilateral boundary between both states and this outer limit does not border on the Area. This is also the case for the lateral boundary between both states in the central Arctic Ocean. Bilateral boundaries may also constitute the outer limit of the continental shelf of other states in large parts of the central basin of the Arctic Ocean. ${ }^{69}$ The overlap of continental shelf areas beyond 200 nautical miles between states does not affect their obligation to make a submission to the CLCS in respect of the outer limits. ${ }^{70}$

The Russian Federation and Norway have not yet concluded an agreement on the delimitation of most of their maritime boundary. ${ }^{71}$ As a consequence, they had to decide for which part of the area beyond 200 nautical miles information would be submitted. Norway and the Russian Federation held consultations on this matter before the submission by the Russian Federation. ${ }^{72}$ Both states agreed that in their submission they would employ as the outer limit of the continental shelf the line

68. Both areas are included in Figure I included in this article.

69. See further the discussion in this section and the subsequent sections on the implementation of Art. 76 in the Arctic.

70. See also Committee on legal issues of the outer continental shelf, note 18 at pp. 226-227.

71. In 1957 Norway and the Soviet Union had agreed upon a maritime boundary in the Varanger Fjord. In 2007, this boundary was newly included in a bilateral treaty and was extended seaward for some 15 nautical miles. The remainder of the bilateral boundary, which has a length of more than 900 nautical miles and which has been the subject of negotiations since 1969, remains to be settled.

72. Note verbale of 20 March 2002 of the Permanent Mission of Norway to the United Nations to the Secretary-General of the United Nations; see also Pravitel'stvo Rossiiskoi Federatsii; Rasporiazhenie (Government of the Russian Federation; Decree) of 24 March 2000 No. 441-r, para. 3. 
which they consider should be the bilateral boundary. In the case of the Russian Federation this is a sector line. Norway takes the position that the maritime boundary has to be an equidistance line. Both states in reaction to the executive summary of the submission of the other state to the Commission - Norway submitted information for these areas in 2006 - indicated that they accepted that the Commission would consider the submission and that the actions of the Commission shall be without prejudice to the delimitation of the continental shelf between Norway and the Russian Federation. ${ }^{73}$

The Commission in its recommendations to the Russian Federation on the Barents Sea advised making a further submission after the entry into force of a bilateral treaty with Norway, as the boundary agreed upon with Norway would constitute the outer limit of the continental shelf of the Russian Federation. ${ }^{74}$ This recommendation at first sight seems somewhat odd because the Commission is not competent to deal with bilateral boundaries between neighbouring states. The approach of the Commission is probably explained by the fact that the Russian Federation had not submitted sufficient information to allow the conclusion that the entire area beyond 200 nautical miles in the Barents Sea was part of the continental shelf and that the Commission did not want to make any statements which might be interpreted to the contrary. Norway, in making its submission for the area in the Barents Sea, has chosen to demonstrate that the area in its entirety is part of the continental shelf in accordance with Article 76 of the Convention. ${ }^{75}$ This is confirmed by the recommendations of the Commission to Norway. ${ }^{76}$ The Commission acknowledged that the information which had been submitted by Norway satisfied the requirements of Article 76 and that only the bilateral delimitation between Norway and the Russian Federation remained to be carried out to determine the exact extent of each state's continental shelf. The Commission did not advise Norway, as had been the case for the Russian Federation, to submit information to the

73. Note verbale of 20 March 2002 of the Permanent Mission of Norway to the United Nations to the Secretary-General of the United Nations; Note Verbale No. 82/n of 21 February 2007 of the Permanent Mission of the Russian Federation to the United Nations to the Secretary-General of the United Nations. For the area of overlapping claims in the Arctic Ocean to the north of Svalbard and Franz Josef Land see also infra.

74. Oceans and Law of the Sea; Report of the Secretary-General; Addendum (A/57/57/Add.1 of 8 October 2002), para. 39.

75. Continental Shelf Submission of Norway in respect of areas in the Arctic Ocean, the Barents Sea and the Norwegian Sea; Executive Summary, p. 12, para. 7.1, p. 13, Figure 4 and Annex 1, p. 20. That Norway would take this approach was already intimated in its note of 20 March 2002 in reaction to the executive summary of the Russian Federation.

76. Summary of the recommendations of the Commission on the Limits of the Continental Shelf in regard to the submission made by Norway in respect of areas in the Arctic Ocean, the Barents Sea and the Norwegian Sea on 27 November 2006 (adopted by the Commission on 27 March 2009 with amendments) p. 9 , paras. $22-24$. 
Commission following the entry into force of a bilateral delimitation treaty. Instead, it recommended that Norway deposit information with the Secretary-General of the United Nations in accordance with Article 84 of the Convention. ${ }^{77}$ It would be possible for the Russian Federation to adopt the Norwegian approach in resubmitting information on the Barents Sea to the Commission.

By far the largest area for which the Russian Federation made its submission to the CLCS in 2001 is located in the central Arctic Ocean. What immediately catches the eye is that the largest part of the submitted outer limits coincides with the sector lines which were used by the former Soviet Union in connection with its claim to islands in the Arctic Ocean. The executive summary of the submission indicates that this concerns provisional limits with neighbouring states, which have to be further determined in bilateral negotiations. ${ }^{78}$ The outer limit of the continental shelf of the Russian Federation in the Arctic Ocean is not constituted entirely by sector lines. This approach confirms that the Russian Federation does not consider that sector lines can be used to claim maritime areas beyond the maritime limits established in accordance with the rules contained in the LOSC.

The Soviet Union and the Russian Federation have taken the position that sector lines are relevant for the delimitation of maritime boundaries with neighbouring states. In the case of the United States this line coincides with the line which has been employed in the 1867 Convention concerning the cession of Alaska between the United States and the Russian Empire to define the extent of Alaska. ${ }^{79}$ In 1990 the United States and the Soviet Union agreed to employ this line as their bilateral maritime boundary ${ }^{80}$ The employment of this line as a consequence does not entail an implicit recognition of the sector principle by the United States.

The definition of the maritime boundary in the 1990 agreement implies that it also delimits the continental shelf beyond 200 nautical miles between the Russian Federation and the United States, to the extent that it overlaps. ${ }^{81}$ The agreement, which is provisionally applied, has not yet entered into force because the Parliament of the Russian Federation has not yet approved its ratification. The boundary defined in the agreement in general is less advantageous to the Russian Federation

77. The recommendations of the Commission imply that it did not consider that Norway would be obliged to meet the requirement concerning the deposit of information on the outer limits of the continental shelf in accordance with Art. 76(9). This approach is justified by the fact that the entire area beyond 200 nautical miles is part of the continental shelf. For the determination of the outer limit of the continental shelf in relation to the Area it does not matter how this area is divided between the coastal states.

78. See Executive Summary, p. 1 and the legend to map 2.

79. Adopted on 30 March 1867 (United States Statutes at Large. Vol. 15, p. 539).

80. Agreement between the United States of America and the Union of Soviet Socialist Republics on the Maritime Boundary of 1 June 1990 ((1990) 29 ILM 941).

81. See ibid., Art. 1. 
than the so-called equidistance line, which has a central role in the law applicable to the delimitation of maritime boundaries between neighbouring states. This law in large part has been developed through the case law of the International Court of Justice and arbitral awards. Initially, it was rejected that equidistance, which is a geometrically objective method and implies a line which is always at an equal distance from the baselines of the interested states, had a special status in the delimitation of maritime zones. The jurisprudence of the last decade has generally adopted the equidistance line as a starting point for effecting a delimitation. The most important circumstance to shift this line to arrive at a final boundary probably is the presence of small islands. If they have a significant impact on the equidistance line if they were to be given full weight, they may, as a result, be given partial or no weight. ${ }^{82}$

The area in the Bering Sea which is delimited by the 1990 Agreement is of importance to fisheries. The equidistance line is advantageous to the United States in that area and also in the area of continental shelf beyond 200 nautical miles in the Arctic Ocean. However, the equidistance line in the latter case for the Russian Federation is determined by basepoints on the small island of Herald. Islands in a similar position have regularly been ignored in the case law in determining maritime boundaries between states.

As was mentioned earlier the negotiations between Norway and the Russian Federation have not yet led to the conclusion of a bilateral delimitation agreement. It is not likely that the delimitation of the area of continental shelf beyond 200 nautical miles to the north of Svalbard and the Russian archipelago of Novaia Zemlia is of major importance in these negotiations. In comparison this concerns a relatively limited area of overlapping claims. The Russian sector line and the equidistance line claimed by Norway diverge much further in the Barents Sea, which is also much more important from a resource perspective. In both cases, under the substantive rules of delimitation law there does not seem to be a basis to accept the sector line as a maritime boundary. ${ }^{83}$ There may be some room for arguing that there are relevant circumstances to justify a shift of the equidistance line to arrive at a final boundary.

The continental shelf of the Russian Federation in the Arctic Ocean may also overlap with the continental shelf of Canada and Greenland (Denmark). In this area the sector line claimed by the Russian Federation also diverges from the equidistance line between the Russian Federation and its neighbouring states. The equidistance line would be more advantageous to the Russian Federation in the

82. A cogent statement of the current law of maritime delimitation is provided by the judgment of the International Court of Justice in the case concerning Maritime Delimitation in the Black Sea (Romania v. Ukraine) of 3 February 2009.

83. See also infra text at n. 184. 
area to the north of the New Siberian Islands. However, in this area this line on the part of the Russian Federation is defined by basepoints on a number of small islands - among others Henrietta and Jeannette. Islands in a similar position have regularly been ignored in the case law when determining maritime boundaries between states. The sector line is more advantageous than the equidistance line to the Russian Federation in the area which is closer to the geographic North Pole. The outer limit contained in the submission by the Russian Federation extends north to this point. If equidistance lines were to be employed as bilateral boundaries, the geographical North Pole would be on the Danish side of that line. Information on the projects of Canada and Denmark for the implementation of Article 76 of the LOSC indicates that in gathering data they take into account the equidistance line bilaterally and in relation to the Russian Federation. ${ }^{84}$ There have not yet been any negotiations on the delimitation of the bilateral boundaries between the Russian Federation and the other two states. ${ }^{85}$

After the Russian Federation had made its submission in 2001 all of its neighbouring states in the Arctic Ocean reacted. It is likely that the Russian Federation had consulted with all of its neighbours beforehand ${ }^{86}$ Reference to the reaction to Norway was already made in connection with the discussion of the continental shelf in the Barents Sea. Canada and Denmark referred to the lack of specific data that would allow a qualified assessment of the Russian Federation's submission and indicate that the absence of comments does not imply agreement to or acquiescence in the submission. ${ }^{87}$ The Notes indicate that it is considered that any recommendations by the CLCS are without prejudice to the delimitation of the continental shelf of the Russian Federation with, respectively, Canada and Denmark.

The most elaborate reaction to the Russian submission was given by the United States. ${ }^{88}$ In the first place, it was remarked that the Russian Federation employed

84. For Denmark see for example, 'Danish-Canadian Bathymetric and Gravimetric Survey of the Arctic Ocean' of 17 March 2009, at <http://a76.dk/cgi-bin/nyheder-m-m.cgi?id=1237357596\%7Ccgi function=form $>$; and for Canada 'Defining Canada's Extended Continental Shelf', at $<$ http://www.inter national.gc.ca/continental/limits-continental-limites.aspx?lang=eng>.

85. See Ministry of Foreign Affairs of the Russian Federation, Press and Information Department, 'Commentary to questions of RIA Novosti on the Russian expedition in an area of the Arctic Ocean' (text in Russian) of 30 July 2007, at $<$ http://www.mid.ru>, in which it is indicated that this question will only be considered once there is a clear scientific and legal basis that the continental shelf of the Russian Federation overlaps with that of its neighbouring states.

86. See Pravitel'stvo Rossiiskoi Federatsii; Rasporiazhenie (Government of the Russian Federation; Decree) of 24 March 2000 No. 441-r, para. 3.

87. Note Verbale No. 0145 of 18 January 2002 of the Permanent Mission of Canada to the United Nations to the Secretary-General of the United Nations; Note Verbale File No. 119.N.8 of 4 February 2002 of the Permanent Mission of Denmark to the United Nations to the Secretary-General of the United Nations.

88. Letter of the Permanent Representative of the United States to the Under-Secretary for Legal Affairs, United Nations, 28 February 2002, Annex. 
the boundary line included in the 1990 agreement with the United States, but that the agreement had not yet been approved by the Duma. The use of this line was found to be in accordance with the interests of both states and Article 9 of Annex II to the LOSC. ${ }^{89}$ The reaction of the United States moreover provides a detailed assessment of the proposed outer limit line. In this connection it is stressed that:

'the integrity of the Convention and the process for establishing the outer limit of the continental shelf beyond 200 nautical miles ultimately depends on adherence to legal criteria and whether the geological criteria and interpretations applied are accepted as valid by the weight of informed scientific opinion. ${ }^{90}$

The commentary of the United States among other things specifies that the Commission has no competence in respect of questions of baselines and that at the same time the Commission should not be seen as endorsing particular baselines. The largest part of the commentary is concerned with the fact that the outer limit of the continental shelf submitted by the Russian Federation also includes parts of two ridges, the Alpha-Mendeleyev Ridge ${ }^{91}$ and the Lomonosov Ridge. Referring to scientific literature, the United States argued that these ridges did not constitute a natural prolongation of the land territory but are separate parts of the ocean floor. The United States proposed a further consideration and a broad debate before any recommendation would be made by the Commission. ${ }^{92}$

The observations of the United States concerning baselines and the AlphaMendeleyev Ridge and the Lomonosov Ridge raise fundamental questions concerning the process for establishing the outer limits of the continental shelf beyond 200 nautical miles under the Convention. The Commission has a clearly defined competence, which only includes legal issues to a limited extent. At the same time legal questions may play an important part in considering the submission of a coastal state. The particular procedure for dealing with a submission in relation to which there exists an unresolved dispute over the continental shelf between neighbouring states or another maritime or territorial dispute might offer a solution in those cases. That would require as a first step that another state would formulate a legal question as a dispute in the sense of Annex I to the Rules of Procedure of the Commission. The United States had not opted for that approach. A second question is which matters are covered by Annex I to the Rules of Procedure of the Commission. One

89. Ibid.

90. Letter of the Permanent Representative of the United States to the Under-Secretary for Legal Affairs, United Nations, 28 February 2002.

91. The Alpha-Mendeleyev Ridge is also referred to as two separate ridges. The present article will employ Alpha-Mendeleyev Ridge throughout.

92. Letter of the Permanent Representative of the United States to the Under-Secretary for Legal Affairs, United Nations, 28 February 2002, Annex. 
view is that this may only concern disputes between neighbouring states. That view has for instance been espoused by Japan. After Japan had lodged its submission in November 2008, China and the Republic of Korea, among others, reacted to it. ${ }^{93}$ Those states observed that a part of the outer limit submitted by Japan was premised on the use of the island of Okinotorishima as a baseline. They submitted that this island is a rock in the sense of Article 121(3) of the LOSC and consequently does not have a continental shelf. Since the Commission is not competent to rule on this matter of treaty interpretation both states requested the Commission to refrain from considering the part of the submission concerning the outer limit of the continental shelf generated from Okinotorishima. Japan, in a reaction, observed that the CLCS is not competent to rule on Article 121 of the Convention and that questions related to baselines are not included in matters covered by Annex I to the Rules of Procedure dealing with maritime and territorial disputes. Japan requested the Commission to disregard the observations of China and the Republic of Korea in considering the submission of Japan. ${ }^{94}$

The Commission in its initial assessment of the matter acknowledged that it had no role in matters relating to the legal of interpretation of Article 121 and decided to revert to the matter when it would establish a subcommission to deal with the submission of Japan. ${ }^{95}$ During its subsequent session the Commission, while reiterating that the Commission was concerned with issues related to Article 76 of and Annex II to the LOSC and that it did not have a role to play in matters relating to the legal interpretation of Article 121, constituted a subcommission to deal with Japan's submission and instructed it also to consider the part of the submission related to Okinotorishima. However, the Commission also decided that it was not to take action on the recommendations of the subcommission in respect of that part of the submission until it would decide to do so. ${ }^{96}$ The approach of the Commission indicates that it does not consider that a dispute in relation to Article 121(3) of the Convention is a dispute in the sense of Annex I to its Rules of Procedure. In that case, the Commission should have refrained from considering the submission in view of the positions of China and the Republic of Korea. ${ }^{97}$ At the same time, the

93. Note Verbale CML/2/2009 of 6 February 2009 of the Permanent Mission of the People's Republic of China to the United Nations to the Secretary-General of the United Nations; Note Verbale MUN/046/09 of 27 February 2009 of the Permanent Mission of the Republic of Korea to the United Nations to the Secretary-General of the United Nations.

94. See CLCS/62 of 20 April 2009, para. 54.

95. Ibid., para. 59.

96. CLCS/64 of 1 October 2009, paras. 23-26.

97. The treatment by the Commission of the submissions of Argentina and Australia in respect of the continental shelf of their Antarctic territories indicates that if a submitting state and third states agree that a matter is a dispute in the sense of Annex I to the Rules of Procedure and the Commission should not consider the submission, the Commission will defer to the views of the states concerned. On this aspect of these submissions see further infra section 5.2.1. 
fact that the Commission has reserved its position on the further procedure following the recommendations of the subcommission on the submission of Japan to the full Commission indicates that the comments of China and the Republic of Korea have had an impact on the process. If the recommendations of the Commission to Australia in relation to the outer limit of the continental shelf of Heard Island and the McDonald Islands were to be applied by analogy, it would stand to reason that the Commission would not include the outer limit line off Okinotorishima in its recommendations. The Commission in that case indicated that as a general principle its recommendations only dealt with issues related to Article 76 and Annex II to the Convention and were without prejudice to matters relating to delimitation between neighbouring states or the application of other parts of the LOSC or any other treaties. ${ }^{98}$ With reference to the latter point the Commission indicated that it was not in a position to make recommendations on a part of the outer limit submitted by Australia. ${ }^{99}$

The comments of China and the Republic of Korea were related to baselines. It is not clear whether the Commission would have acted in a similar fashion if the comments would have been concerned with the interpretation or application of Article 76, as was the case for part of the observations of the United States on the submission of the Russian Federation. The general principle contained in the recommendations to Australia referred to above suggests that the Commission may view Article 76 differently from other parts of the Convention.

The observations of the United States also point to the alleged lack of openness of the procedure under Article $76 .{ }^{100}$ Whether this is actually a problem is questionable. ${ }^{101}$ First of all, the procedure for establishing the outer limits of the continental shelf under the LOSC does not envisage a role for third states in the consideration of the submission of the coastal state by the Commission. ${ }^{102}$ However, two observations are apposite. The fact that the Commission tends towards a

98. Summary of the Recommendations of the Commission on the Limits of the Continental Shelf (CLCS) with regard to the submission made by Australia on 15 November 2004; Recommendations adopted by the Commission on 9 April 2008, para. 5

99. See also infra section 5.2.3.

100. The view that there is a problematic lack of openness in the procedure has been expressed in a number of publications (see for instance R. Macnab, 'The Case for Transparency in the Delimitation of the Outer Continental Shelf in Accordance with UNCLOS Art. 76', 35 Ocean Development and International Law (2004) pp. 1-17; G. Taft, 'Applying the Law of the Sea Convention and the Role of the Scientific Community relating to Establishing the Outer Limit of the Continental Shelf Where It Extends Beyond the 200 Mile Limit', in M.H. Nordquist, R. Long, T.H. Heidar and J.N. Moore, eds., Law, Science and Ocean Management (Leiden, Martinus Nijhoff Publishers 2007) pp. 469-476).

101. See also A.G. Oude Elferink, "“Openness" and Article 76 of the Law of the Sea Convention: The Process Does Not Need to Be Adjusted', 40 Ocean Development and International Law (2009) pp. 36-50.

102. See ibid., p. 37. 
restrictive interpretation of Annex I to its Rules of Procedure limits the possibilities of third states to impact on controversial issues previous to the consideration of a submission. At the same time, the practice of the Commission points to the fact that it has a significant impact on the interpretation of Article 76. ${ }^{103}$ This combination may lead to a situation in which the interpretation of Article 76 to a large part is beyond the purview of the States Parties to the Convention. ${ }^{104}$ In view of the circumscribed competence of the CLCS it is questionable whether this outcome was envisaged at UNCLOS III. It is of course true that at least as far as questions which are clearly beyond the competence of the Commission, such as baselines, are concerned, outer limits established on the recommendations of the Commission do not prejudice the position of third states. However, even in those cases restraint might be commendable. ${ }^{105}$ There is a certain irony to the present development of the practice of the Commission. Article 76(10) of the Convention and Article 9 of Annex II to the Convention explicitly safeguard the position of other states in respect of bilateral boundaries. Nonetheless, procedures have been created which may even lead to the absence of a submission in the case of a pending bilateral delimitation or to blocking the submission of a state by a neighbouring state. The practice of the Commission indicates that non-neighbouring states are not afforded similar procedural opportunities although their rights, and those of the international community in respect of the Area, may be affected in a similar way as those of neighbouring states.

However, let us return to the 2001 submission of the Russian Federation. In its presentation to the Commission, the Russian Federation, presaging the observations of Japan in respect of Okinotorishima, pointed out that the reaction of the United States indicated that a dispute concerning the delimitation of maritime zones did not exist. ${ }^{106}$ As far as can be ascertained the other observations of the United States were not commented upon. It is not known to what extent the comments of the United States on the Russian Federation's submission played a role in its consideration. In the case of the subsequent submission by Brazil, the Commission explicitly instructed the subcommission dealing with the submission not to take the observations of the United States into account. ${ }^{107}$ This makes it likely that the

103. See supra the text at $\mathrm{n} .15$ et seq.

104. The scope for a review of the recommendations of the Commission in a third party dispute settlement between states Parties to the Convention is limited (see e.g., Committee on legal issues of the outer continental shelf, $n .18$ at pp. 245-248).

105. In that respect, the treatment of third states in the adjudication of bilateral boundaries possibly provides an interesting example.

106. Statement made by the Deputy Minister for Natural Resources of the Russian Federation during the presentation of the submission made by the Russian Federation to the Commission, made on 28 March 2002 (CLCS/31 of 5 April 2002), p. 6.

107. Statement by the Chairman of the CLCS on the progress of the work in the Commission (CLCS/42 of 14 September 2004), para. 17. 
United States' commentary also did not have any (formal) role in the consideration of the submission of the Russian Federation.

The Commission as regards the Arctic Ocean recommended the Russian Federation to make a revised submission based on the findings contained in the recommendations. ${ }^{108}$ Further information on the content of the recommendations is not available. It is however likely that the Commission in particular took issue with the role of the Alpha-Mendeleyev Ridge and the Lomonosov Ridge in establishing the outer limits of the continental shelf of the Russian Federation. In this respect two issues could possibly have been relevant. The outer limit of the continental shelf along the ridges extended beyond 350 nautical miles. In other words, the Russian Federation considered that the Alpha-Mendeleyev Ridge and the Lomonosov Ridge were not submarine ridges in the sense of Article 76(6) of the Convention, in which case the outer limit of the continental shelf shall not exceed 350 nautical miles. The Commission may have concluded either that the submission pointed to the fact that the Alpha-Mendeleyev Ridge and the Lomonosov Ridge are submarine ridges in the sense of Article 76(6) or that these ridges did not form a natural prolongation of the land territory of the Russian Federation. In the latter case they cannot contribute at all to the definition of the outer limit of the continental shelf.

It has been suggested that the Commission rejected the interpretation of the Russian Federation in respect of the Alpha-Mendeleyev Ridge and the Lomonosov Ridge because there is a morphological break between the ridges and the adjacent continental margin. ${ }^{109}$ On the other hand, an article by Hinz, a former member of the Commission, seems to suggest that the Commission considered that the ridges were covered by the first sentence of Article 76(6). ${ }^{110}$ The article does not state explicitly that the Commission reached this conclusion, but indicates that the classification of the Kerguelen Plateau south of Heard Island and the McDonald Islands as either a submarine ridge or a submarine elevation might have a huge impact on the establishment of the outer limits of the continental shelf in the Arctic. Hinz, in his article, refers to a number of scientific publications which conclude that the Southern Kerguelen Plateau is a submarine ridge in the sense of Article 76(6). ${ }^{111}$

108. See Oceans and Law of the Sea; Report of the Secretary-General; Addendum (A/57/57/Add. 1 of 8 October 2002), para. 41.

109. R. Macnab, 'Submarine Elevations and Ridges: Wild Cards in the Poker Game of UNCLOS Article 76', 39 Ocean Development and International Law (2008) pp. 223-234 at p. 226.

110. K. Hinz, 'Wem gehört die zentrale Arktis um den Nordpol und wer ist zuständig für den Festlandsockel der Antarktis? Wichtige Aspekte des Artikels 76 des Internationalen Seerechtübereinkommens der Vereinten Nationen', 77 Polarforschung (2007) pp. 55-70 at pp. 60-61 and 63. See also the remarks at the end of the next paragraph.

111. Ibid., pp. 61-62. An analysis of the Australian submission by the de United States Geological Service concludes that existing studies do not demonstrate that the Southern Kerguelen Plateau is a natural prolongation of Heard Island and the McDonald Islands (D.R. Hutchinson and R.W. Rowland, USGS Analysis of the Australian UNCLOS Submission (Report Series 2006-1073) p. 11). 
The Australian submission to the Commission did not classify the Southern Kerguelen Plateau as a submarine ridge. The outer limit of the continental shelf in this area extends for over 600 nautical miles south of Heard Island and the McDonald Islands. ${ }^{112}$ The Commission has agreed to this interpretation by Australia. ${ }^{113}$ To what extent these findings will really constitute a precedent for the Arctic remains to be seen. Further research by the Russian Federation has been aimed at gathering geological and geomorphological data to prove that the ridges are part of the continental margin. ${ }^{114}$ The fact that the Russian Federation still considers that its continental shelf extends to the area of the geographical North Pole indicates that it is considered that the limit of 350 nautical miles in Article 76(6) is not applicable to the ridges.

A part of the outer limit of the continental shelf of the Russian Federation in the Arctic Ocean - to the north of Franz Josef Land - is not concerned with the AlphaMendeleyev Ridge and the Lomonosov Ridge. In view of the recommendations of the Commission in 2002 for this area there was also insufficient data to issue a recommendation on the location of the outer limit of the continental shelf. ${ }^{115}$

One final point of interest in respect of the submission of the Russian Federation is that it implied a more restrictive interpretation of Article 76(7) than was later advanced by certain other states. From the submission of Australia and the consideration by the Commission it can be concluded that fixed points, which were located on the outer limit of the 200-nautical-mile zone of Australia and were presented as a fixed point determined in accordance with Article 76(7), did not meet the requirements of Article 76(4) of the LOSC. ${ }^{116}$ The Commission did not accept the approach of Australia, which implied that any point at 200 nautical miles may

112. Continental Shelf Submission of Australia, Executive Summary, p. 17 and Figures 8 and 9.

113. That the conclusions of the Commission differ from the above-mentioned analyses may in part be explained by the fact that the Commission, apart from the existing literature, also disposed of data which had been gathered by Australia in the preparation of its submission (see also Summary of the Recommendations of the Commission on the Limits of the Continental Shelf (CLCS) with regard to the submission made by Australia on 15 November 2004; Recommendations adopted by the Commission on 9 April 2008, para. 47). A preliminary study on the application of Article 76 to Australia's continental shelf from 1988 had concluded that Article 76 should allow Australia to claim all of the Southern Kerguelen Plateau, but also observed that there existed uncertainty over the continental origin of the Southern Kerguelen Plateau (P. Symonds and J.B. Wilcox, Definition of the continental margin using U.N. Convention on the law of the sea (Article 76), and its application to Australia (Bureau of Mineral Resources Geology and Geophysics (Record No. 1988/38) p. 14).

114. See Macnab, supra n. 109, at p. 226; and ITAR-TASS, 'Russia to make to UN its stake to fix Arctic shelf limits' of 6 August 2007 reporting on remarks by a representative of the Ministry of Natural Resources of the Russian Federation.

115. See also infra text at nn. 136 and 137.

116. For issues of interpretation in this connection see Committee on legal issues of the outer continental shelf, supra n. 18, at pp. 223-225. 
be used as a fixed point in the sense of Article 76(7). ${ }^{117}$ Did the Commission in its consideration of this point deal with the interpretation of Article 76? One might argue that this concerned a purely scientific and technical question. Australia had used fixed points, which were demonstrably not in accordance with the criteria contained in Article 76(4). The Commission is competent to issue recommendations on that matter. On the other hand, it is doubtful whether the Commission would be competent to rule on the legal interpretation on which the submission of of Australia was based. ${ }^{118}$ The Commission seems to have tried to base its approach on the former view, but may have also engaged in considering legal matters. Before adopting its recommendations on the submission of Australia, the Commission discussed the general principles involved, which 'focused on the technical aspects of the issue'. ${ }^{119}$ At the same time the addition that it also concerned the relationship to the entitlement to the continental shelf beyond 200 nautical miles ${ }^{120}$ suggests the inclusion of legal issues in that discussion.

The Russian Federation has indicated that it expects to make a new submission to the Commission in 2010. The Rules of Procedure of the Commission do not indicate how the Commission will queue new or revised submissions resulting from recommendations to the coastal State to do so. The provision on the queuing of submissions contained in Rule 51 suggests that the submission would be queued after the last submission in the line. ${ }^{121}$

117. See Summary of the Recommendations of the Commission on the Limits of the Continental Shelf (CLCS) with regard to the submission made by Australia on 15 November 2004; Recommendations adopted by the Commission on 9 April 2008, para. 8 (general approach) and para. 19 (an example of application to a specific outer limit line).

118. See supra $\mathrm{n} .24$.

119. Statement by the Chairman of the Commission on the Limits of the Continental Shelf on the progress of work in the Commission (CLCS/50 of 10 May 2006) para. 29.

120. Ibid.

121. On the other hand, the consideration of the submission of Brazil by the Commission seems to indicate that in that process a coastal state is allowed to submit additional information even if it results in significant departures from the originally proposed outer limits of the continental shelf (see Statement by the Chairman of the Commission on the Limits of the Continental Shelf on the progress of work in the Commission (CLCS/48 of 7 October 2005) paras. 18-19; and Letter dated 25 August 2005 from the Legal Counsel, Under-Secretary-General of the United Nations for Legal Affairs, addressed to the Chairman of the Commission on the Limits of the Continental Shelf: Legal opinion on whether it is permissible, under the United Nations Convention on the Law of the Sea and the rules of procedure of the Commission, for a coastal State, which has made a submission to the Commission in accordance with article 76 of the Convention, to provide to the Commission in the course of the examination by it of the submission, additional material and information relating to the limits of its continental shelf or a substantial part thereof, which constitute a significant departure from the original limits and formulae lines that were given due publicity by the Secretary-General of the United Nations in accordance with rule 50 of the rules of procedure of the Commission (CLCS/46 of 7 September 2005), especially at pp. 11-13). 


\subsubsection{Norway}

In November 2006, Norway was the second state in the Arctic to make a submission to the Commission. Apart from the Barents Sea, which is discussed in section 4.2.1 above, the submission was concerned with an area in the Arctic Ocean to the north of the archipelago of Svalbard and an area in the Norwegian Sea between the archipelago, the Norwegian mainland and the island of Jan Mayen. ${ }^{122}$ Norway has sovereignty over the archipelago of Svalbard, which has been recognized through the Treaty concerning the Archipelago of Spitsbergen of 1920. ${ }^{123}$ Apart from recognizing the sovereignty of Norway over the archipelago, the Treaty accords equal rights to the nationals of the other Parties in respect of particular economic activities. These provisions of the Treaty are applicable to the territory of Svalbard, including the territorial waters (Art. 3). Subsequently, the question has arisen if the Treaty has any implications for the maritime zones beyond the territorial sea, such as the continental shelf. Norway has taken the position that the Treaty is not applicable to the continental shelf and fishery zone of Svalbard, but this view is not generally accepted. Other states in general do seem to accept that the Treaty does not impose any restrictions on Norway as far as the determination of the extent of maritime zones is concerned. ${ }^{124}$ In the executive summary of its submission Norway did not include any reference to the Treaty concerning the Archipelago of Spitsbergen. This implied that Norway took the view that the implementation of Article 76 did not raise any questions in respect of the Treaty. ${ }^{125}$

The Russian Federation and Spain reacted to the submission of Norway in respect of the area in the Arctic. ${ }^{126}$ The Russian Federation pointed to the ongoing delimitation talks and agreed to the consideration of the submission by the Commission on the basis of the agreement that this is without prejudice to the delimitation between both states. The Russian Federation also indicated that its reaction

122. In view of the definition of the Arctic employed in the present article, the latter area will not be taken into consideration.

123. 2 League of Nations Treaty Series p. 8. Adopted on 9 February 1920; entry into force 14 August 1925.

124. For an exhaustive discussion of these questions see G. Ulfstein, The Svalbard Treaty; From Terra Nullius to Norwegian Sovereignty (Oslo, Scandinavian University Press 1995). For a more recent discussion see D.H. Anderson, 'The status under international law of the maritime areas around Svalbard', 40 Ocean Development and International Law (2009) pp. 373-384.

125. See also Rules of Procedure of the Commission on the Limits of the Continental Shelf, Annex I, para. 2.

126. Note No. 82/n Note Verbale of 21 February 2007 of the Permanent Mission of the Russian Federation to the United Nations to the Secretary-General of the United Nations; Note Verbale of 3 March 2007 of the Permanent Mission of Spain to the United Nations to the Secretary-General of the United Nations. 
was without prejudice to the position of the Russian Federation in respect of the Treaty concerning the Archipelago of Spitsbergen and accordingly to the regime of the maritime zones around Svalbard. ${ }^{127}$

The note verbale of Spain is also concerned with the Treaty concerning the Archipelago of Spitsbergen. Spain indicated that it did not wish to pronounce itself on the competence of Norway to establish new maritime zones from Svalbard, but wished to reiterate that the Treaty provisions concerning equal access were also applicable to the continental shelf. In a reaction to the Spanish note verbale Norway indicated that the issues raised by Spain did not affect in any manner the interpretation or application of the rules contained in Article 76 of Annex II to the LOSC. ${ }^{128}$

Svalbard is relevant to the determination of the outer limit of the continental shelf beyond 200 nautical miles for all three areas included in the submission of Norway in 2006. In all three cases this shelf (also) is adjacent to the 200-nauticalmile zone of Svalbard and in two cases certainly in its entirety is (also) a natural prolongation of the land territory of Svalbard. Does this imply that these areas as a consequence would also fall under the regime of the Treaty concerning the Archipelago of Spitsbergen, if that regime would also apply to the maritime zones of the archipelago? The internal delimitation of the 200-nautical-mile zone between the Norwegian mainland and Bear Island, which is part of the archipelago, sets a precedent for answering this question. In this case the limit between the two areas coincides with the outer limit of the 200-nautical-mile zone of the Norwegian mainland, which implies that no weight is given to Bear Island in establishing this internal limit. As far as is known the other Parties to the Treaty concerning the Archipelago of Spitsbergen have not objected to this internal delimitation. ${ }^{129}$ Norway might opt to apply the same approach in respect of areas which under Article 76 are part of the continental shelf of Svalbard and of the Norwegian mainland or Jan Mayen. ${ }^{130}$ This is the case for the areas in the Norwegian Sea and the Barents Sea. In the case of the area to the north of Svalbard this approach cannot be applied to the whole area concerned. Although this area is also a natural prolongation of the Norwegian

127. Art. 3 of the 2006 delimitation agreement between Denmark and Norway also contains a without prejudice clause. According to the Danish parliamentary papers the interpretation of the Treaty concerning the Archipelago of Spitsbergen is one of the matters covered by this clause (Forslag til folketingsbeslutning (B 114 (2005-2006), at <http://www.ft.dk/Samling/20051/beslutningsforslag/ B114/som fremsat.htm>, para. 2).

128. Note Verbale of 28 March 2007 of the Permanent Mission of Norway to the United Nations to the Secretary-General of the United Nations.

129. Cf., the judgment of the International Court in the Jan Mayen case, [1993] ICJ Rep., pp. 7576 paras. $82-84$.

130. See also Anderson, supra n. 124, at pp. 377-378. 
mainland, it in part is only located within 350 nautical miles of Svalbard, which in this case constitutes the applicable constraint line of Article 76(5). In an internal delimitation all other areas might be designated as being part of the continental shelf of the Norwegian mainland (or Jan Mayen). As a matter of fact Norway has adopted this approach in the Act on petroleum activities of 29 November 1996, which provides that it also applies to the continental shelf (section 1(4)). The Act does not apply to Svalbard and its territorial waters (ibid.). The Act defines the outer limit of the continental shelf by reference to the criteria contained in Article 76(1) of the LOSC (section 1(6)(1)). Norway has adopted this approach since it first enacted this legislation in $1963 .^{131}$

The outer limit of the continental shelf in the Arctic Ocean included in the Norwegian 2006 submission is situated some tens of nautical miles to the north of the outer limit of the 200-nautical-mile zone of Svalbard. The most western point of this outer limit is located on the outer limit of the 200-nautical-mile zone of Greenland. ${ }^{132}$ This approach has been adopted by many other states in making a submission to the Commission. ${ }^{133}$ Earlier in 2006 Denmark and Norway had concluded an agreement concerning the delimitation of the boundary within 200 nautical miles of Greenland and Svalbard. ${ }^{134}$ The preamble to that agreement provides that the parties will address the delimitation of the maritime areas to the north and south of the 200 nautical miles subsequently in connection with the establishment of the outer limit of the continental shelf. ${ }^{135}$

131. See also Koivurova, supra n. 58 , at p. 488 , note 47.

132. Continental Shelf Submission of Norway in respect of areas in the Arctic Ocean, the Barents Sea and the Norwegian Sea; Executive Summary, p. 16.

133. Certain states have also made a submission in respect of areas within 200 nautical miles of another state. This, for instance, seems to be the case for the Russian Federation in respect of the Barents Sea. The maps accompanying the executive summary of the submission only indicate the outer limit of the Russian 200-nautical-mile zone. The outer limit of the continental shelf beyond 200 nautical miles is in part within 200 nautical miles of Norway, as is also indicated by Figure I included in this article (on this issue see also text at note 203).

134. Agreement between the Government of the Kingdom of Norway, on the one hand, and the Government of the Kingdom of Denmark together with the Home Rule Government of Greenland, on the other, concerning the delimitation of the continental shelf and the fisheries zones in the area between Greenland and Svalbard. Adopted on 20 February 2006; entry into force 2 June 2006.

135. The Danish reaction to the submission of Norway is only concerned with the area to the south of the 200-nautical-mile zones of Svalbard and Greenland (Note Verbale Ref. No. 119.N.8 of 24 January 2007 of the Permanent Mission of Denmark to the United Nations to the Secretary-General of the United Nations). Preliminary information concerning the Danish continental shelf beyond 200 nautical miles also indicates that there is only an area of overlapping entitlements in the southern area $(\mathrm{C}$. Marcussen et al., 'Exploring for extended continental shelf claims off Greenland and the Faroe Islands - geological perspectives', 4 Geological Survey of Denmark and Greenland Bulletin (2004) pp. 61-64 at p. 61 and the figure of the potential outer limits of the continental shelf to the north of Greenland in Området nord for Grønland, at <http://a76.dk/greenland/north/index.html $>$. 
The most eastern point of the outer limit contained in Norway's submission in respect of Svalbard lies to the west of the area which is the subject of delimitation talks with the Russian Federation. Norway and the Russian Federation previously agreed that this point will be connected with the most western fixed point of the final outer limit of the Russian Federation by a straight line not exceeding 60 nautical miles. ${ }^{136}$ This point differs from the most western point which the Russian Federation had submitted to the Commission in 2001. This suggests that the Russian Federation in the meantime had gathered additional information. ${ }^{137}$

The Commission adopted recommendations in respect of the submission of Norway on 27 March 2009. A general observation by the Commission on its recommendations to Norway is pertinent to the Treaty concerning the Archipelago of Spitsbergen:

'The Recommendations of the Commission are based on the scientific and technical data and other material provided by Norway in relation to the implementation of Article 76. The Recommendations of the Commission only deal with issues related to Article 76 and Annex II to the Convention and are without prejudice to matters relating to delimitation between States, or application of other parts of the Convention or any other treaties. ${ }^{138}$

In the case of the Arctic Ocean, the recommendations on a number of points diverge from Norway's submission. The subcommission dealing with the Norwegian submission had indicated that the data provided by Norway in one case did not sufficiently prove the location of the foot of the continental slope and recommended Norway to employ a more landward point. Norway subsequently submitted additional information, which resulted in a more seaward foot of slope point. This new point also led to a more seaward location of the outer limit of the continental shelf. ${ }^{139}$ The summary of the recommendations of the Commission indicates that the Commission will in principle work towards recommendations through a dialogue with the submitting state. Norway has amended or supplemented the original submission on more than one occasion or proposed different points. ${ }^{140}$ Norway has indi-

136. Continental Shelf Submission of Norway in respect of areas in the Arctic Ocean, the Barents Sea and the Norwegian Sea; Executive Summary, p. 14.

137. See also ibid.

138. Summary of the recommendations of the Commission on the Limits of the Continental Shelf with regard to the submission made by Norway in respect of areas in the Arctic Ocean, the Barents Sea and the Norwegian Sea on 27 November 2006 (adopted by the Commission on 27 March 2009 with amendments), section III, para. 8 .

139. Ibid., pp. 11-16. The difference between the two limits is not discernable at the scale of Figure I included in this article.

140. In the case of the Norwegian Sea this has led to a landward shift of the outer limit which was initially submitted (see ibid., paras. 79-80). 
cated that it will comply with the recommendations of the Commission. The Norwegian Minister of Foreign Affairs has declared that ' $[t]$ he recommendations provide a basis on which Norway can establish the limits of its continental shelf in the High North'. ${ }^{141}$

\subsubsection{Canada, Denmark and the United States}

The three other coastal states of the Arctic Ocean have thus far not made a submission to the Commission. For Canada and Denmark the final date for their submission falls in respectively 2013 and 2014. In the case of the United States, which has yet to accede to the Convention, the 10-year time limit has not started running. All three states are actively engaged in gathering data and it is to be expected that they will make a submission to the Commission in due time.

The extent of the continental shelf beyond 200 nautical miles of Canada and Denmark in the Arctic Ocean depends most of all, as is the case for the Russian Federation, on the question whether the Alpha-Mendeleyev Ridge and the Lomonosov Ridge are a natural prolongation of their land territory and whether or not these ridges are submarine ridges in the sense of Article 76(6) of the LOSC. The equidistance line between Canada and Denmark runs along the Lomonosov Ridge, while the Alpha-Mendeleyev Ridge lies north of Ellesmere. Both states collaborate in the gathering of information in this area. ${ }^{142}$ Like the Russian Federation, Canada and Denmark have not limited themselves to the area within 350 nautical miles from their baselines. The importance of the classification of these ridges is emphasized by the joint Lomonosov Ridge - Test of Appurtenance (LORITA) project. Both states, within the framework of this project, did not only collaborate in the gathering of data, but also in the interpretation of that data. It is considered that this collaboration will reinforce the case of both states. ${ }^{143}$ Current information on the potential outer limit of Denmark in the area north of Greenland indicates that the outer limits do not extend to the equidistance line with Norway. ${ }^{144}$

141. Extent of Norway's continental shelf in the High North clarified (Press release 15.04.2009 No. 025/09 of the Ministry of Foreign Affairs of Norway), at $<$ http://www.regjeringen.no/en/dep/ud/ press $/$ News/2009/shelf_clarified.html?id $=554718>$.

142. See for instance 'Danish-Canadian Bathymetric and Gravimetric Survey of the Arctic Ocean', note 84 .

143. See further E. Riddell-Dixon, 'Canada and Arctic Politics: The Continental Shelf Extension', 39 Ocean Development and International Law (2008) pp. 343-359 at p. 350; Foreign Affairs and International Trade Canada, 'International Collaboration; Collaboration with Denmark', at $<\mathrm{http}: / /$ www.international.gc.ca/continental/collaboration.aspx>>

144. See the figure of the potential other limits of the continental shelf to the north of Greenland in Området nord for Grønland, at $<\mathrm{http} / / \mathrm{a} 76 . d \mathrm{k} /$ greenland/north/index.html $>$. The legend to the figure indicates that it is based on limited data, and the assumption that the Lomonosov Ridge is a submarine elevation. 
If both Canada and Denmark as well as the Russian Federation were to prove that the Alpha-Mendeleyev Ridge and the Lomonosov Ridge are a part of their continental shelf, this would lead to an overlapping area between the three states. That overlap would however only exist if these ridges do not fall under Article 76(6). If that were to be the case - for one or more of the states and one or both ridges - the continental shelf in that case would only extend to 350 nautical miles. ${ }^{145}$ Whether that will be the case is difficult to judge at this point in time. The bilateral delimitation with the Russian Federation was already discussed previously. Reportedly, Canada and Denmark in principle accept the equidistance method for the delimitation of their bilateral boundary, which seems to be a logical choice in view of the relevant coastal geography. Interestingly, a map of the Arctic published by Natural Resources Canada depicts a boundary line which follows the equidistance line to approximately the 200-nautical-mile limit, but seaward of that point uses a meridian up to the geographic North Pole. ${ }^{146}$ The meridian is more advantageous to Canada than the equidistance line for that area.

Canada is also considering the outer limits of the continental shelf beyond 200 nautical miles in the western Arctic. This area is unrelated to the Alpha-Mendeleyev Ridge and the Lomonosov Ridge. This area may overlap with the continental shelf beyond 200 nautical miles of the United States. Canada has taken the position that the bilateral boundary of the 200-nautical-mile zones should be the meridian which is also the land boundary between Canada and Alaska. The United States has rejected the relevance of this line and maintains that the equidistance method is appropriate in this case. Interestingly, a large part of the area beyond 200 nautical miles is seaward of both lines.

Canada's programme to gather data in connection with the preparation of a submission for this area extends beyond the notional extension of the meridian which constitutes the land boundary. ${ }^{147}$ One might speculate that the extent of Canada's continental shelf beyond the meridian may become a factor which might impact on in reaching an overall agreement on the bilateral boundary between Canada and the United States. ${ }^{148}$ Canada and the United States have engaged in similar cooperation as Canada and Denmark in respect of data gathering. That cooperation is without prejudice to the views of both states as to the location of their maritime boundary. ${ }^{149}$

145. For the location of the 350-nautical-mile line in this area see Figure I.

146. North Circumpolar Region (2008), at $<$ http://atlas.nrcan.gc.ca/site/english/maps/archives/ reference/circumpolar/MCR0001_circumpolar_2008>.

147. For the location of the equidistance line and the meridian of $141^{\circ} \mathrm{W}$ see Figure I.

148. The map to which reference is made at footnote 146 indicates the meridian as a boundary for the area up to the geographical North Pole.

149. See further '2009 U.S. - Canada Arctic Continental Shelf Survey', at $<$ http://continentalshelf. gov/missions.html>; Transcription/Transcription News Conference/Conférence De Presse Date/Date: 
The continental shelf of the United States beyond 200 nautical miles in the Arctic Ocean comprises the Chukchi Cap and the Northwind Ridge. According to a preliminary study concerning the extent of the continental shelf of the United States, the outer limit in this area would mostly be determined by the constraint line of 100 nautical miles beyond the isobath of 2500 meters. This would imply that the continental shelf in this area might extend to approximately 600 nautical miles from the coast. ${ }^{150}$ During UNCLOS III the United States explicitly stated that support for Article 76(6) rested on the understanding that it was recognized that the Chukchi Plateau ${ }^{151}$ could not be considered to be a ridge and was covered by the provision on submarine elevations contained in that paragraph. ${ }^{152}$ The statement implies that the constraint of 350 nautical miles would not be applicable to the Chukchi Cap and the Northwind Ridge. The significance of the statement is in principle limited, also in the light of the role of the travaux préparatoires in the interpretation and application of Article 76.

On the basis of current information it seems that the continental shelf of the United States overlaps with that of the Russian Federation and of Canada. The implications of those possible overlaps were discussed previously.

5. THE IMPLEMENTATION OF ARTICLE 76 IN ANTARCTICA

\subsection{Article 76 of the Convention and the Antarctic Treaty: Maintaining constructive ambiguity}

States with a territorial claim in Antarctica were faced with the question how they might at the same time meet their obligations under Article 76 of LOSC and Article IV of the Antarctic Treaty. Article 76 provides for a procedure which results in final and binding outer limits of the continental shelf and the implementation of Article

September 10, 2009 1:00 p.m. (Minister of Natural Resources Lisa Raitt, Along with Canadian and US Officials, Discusses the Preliminary Results of the Joint Scientific Survey in the Arctic) at $<\mathrm{http}: / /$ continentalshelf.gov/media/ecs_transcript_sept1009.doc>.

150. See L. Mayer, M. Jakobsson and A. Armstrong, The Compilation and Analysis of Data Relevant to a U.S. Claim Under United Nations Law of the Sea Article 76: A Preliminary Report (Durham, $\mathrm{NH}$, Center for Coastal and Ocean Mapping/Joint Hydrographic Center University of New Hampshire 2002) pp. 55-57. More recent data indicate that the continental shelf in this area is probably more extensive than was estimated in this study (see Extended Continental Shelf; Fact Sheet (State Department; Bureau of Oceans and International Environmental and Scientific Affairs; 9 March 2009)). This is probably explained by the fact that better seafloor mapping has provided more data on the 2500 meter isobath resulting in the identification of more seaward points of the 2,500 meter isobath.

151. This term is also used to designate the area of the Chukchi Cap and the Northwind Ridge.

152. Third United Nations Conference on the Law of the Sea; Official Records, Vol. XIII, p. 43, para. 156. 
76 might be considered as being contrary to Article IV. On the other hand, a failure to make a submission to the CLCS would be contrary to the obligations of coastal states under the LOSC.

An article by Serdy argues that the implementation of Article 76 would not be contrary to Article IV of the Antarctic Treaty. ${ }^{153}$ There is certainly a great deal to be said for this argument if the text of Article IV is viewed in isolation. If Article IV is considered in the light of the subsequent practice of the states participating in the ATS, which among other things concerns the approach to the definition of maritime zones adopted under other instruments which form part of the ATS, this argument seems less convincing. ${ }^{154}$ In other words, the approach of the claimant states can be seen as a contribution to maintaining the constructive ambiguity which characterizes the ATS.

The establishment of the outer limit of the continental shelf in the framework of the ATS had already been considered in connection with the negotiation of CRAMRA. As was mentioned previously, the procedure contained in CRAMRA raises a number of questions as to its implementation. Since CRAMRA was not going to enter into force in the near future, it in any case did not offer an appropriate framework for the implementation of Article 76.

As far as can be ascertained, the implementation of Article 76 in Antarctica was first discussed by the claimant states in Lima, where they attended the 23rd meeting of the consultative parties to the Antarctic Treaty (ATCM), which took place in May and June 1999. ${ }^{155}$ These consultations throughout their duration in large part remained limited to the claimant states. The only other states which from time to time were involved and probably also exerted a certain influence were the United States and the Russian Federation. The claimant states did consider a number of solutions which would have required the involvement of a larger number of states.

One option, which was initially considered, was a resolution of the ATCM, to which reference could have been made in other fora, or in making a submission to the Commission. This option has a number of drawbacks, which probably explain why it was not further pursued. Draft resolutions indicated that in a resolution a large number of delicate legal questions would have to be addressed. This probably would have led to difficult negotiations between the claimant states and subsequently the draft resolution would also have to be agreed upon in the ATCM. Finally, addressing this matter, which had obvious implications for the general law

153. A. Serdy, 'Some views are more equal than others: Submissions to the Commission on the Limits of the Continental Shelf and the strange loss of confidence in Article IV of the Antarctic Treaty', 28 Australian YIL (2008) (forthcoming).

154. It is likely that this practice would constitute subsequent practice or an agreement in the sense of Art. 31 on treaty interpretation of the Vienna Convention on the law of treaties.

155. This section is in part based on information from persons who have been directly involved in these discussions. 
of the sea, through the ATCM might have led to objections from states which were not represented in the ATCM.

Other proposals to reach an agreement on the problems involving the implementation of Article 76 in Antarctica focused on the institutional frameworks of the LOSC. This mostly concerned the Commission and the Meeting of States Parties, although initially it was also suggested that the International Seabed Authority (ISA) might have a role to play. ${ }^{156}$ In view of the fact that the ISA does not have a role in respect of the establishment of the limits of the continental shelf and the Area, ${ }^{157}$ and this is also likely to be considered undesirable by most states, it is not surprising that this suggestion did not get any significant attention. A role for the Commission and the Meeting of States Parties was more obvious because both institutions had already played a role in further defining the framework in which submissions by coastal states was to take place.

At the very moment when the claimant states started their consultations on Article 76, a discussion had started within the framework of the LOSC on the question of how to deal with the fact that many coastal states, for which 16 November 2004 would be the final date for making a submission to the Commission, had difficulty in meeting that deadline. A number of claimant states suggested that a solution to address the problems in meeting the deadline could also be used to find a solution to the implementation of Article 76 in Antarctica. It was among other things suggested that among the reasons for the deferral of submissions reference could not only be made to the problems encountered by in particular developing states in implementing in Article 76, because of a lack of, among other things, financial means and technical expertise, but also to the problems encountered in collecting data in areas with particular climatological circumstances, such as the presence of sea ice.

Previous to the 11th Meeting of States Parties to the LOSC in May 2001 a number of solutions to address the problems in meeting the deadline for making submissions to the Commission was considered in a background document prepared by the secretariat. ${ }^{158}$ This document identified the 'uncertainties resulting from the geophysical structure of the continent (e.g., ice-covered areas)' as one of the reasons why a state, despite good faith efforts, would only make a partial submission. ${ }^{159}$ As possible solutions to the problem of the deadline the document referred, among other things, to an agreement relating to the implementation of the LOSC, a

156. The ISA is primarily responsible for regulating the exploration and the exploitation of the mineral resources of the Area.

157. See LOSC, Art. 134(4).

158. Issues with respect to Art. 4 of Annex II to the United Nations Convention on the Law of the Sea; Background paper prepared by the Secretariat (SPLOS/64 of 12 May 2001).

159. Ibid., para. 56 (footnote omitted). 
formal amendment to the Convention and a decision of the Meeting of States Parties. The possibility of an implementation agreement had also been considered in the consultations between the Antarctic claimant states and a draft for such an agreement, based on the Implementation Agreement on Part XI of the Convention, ${ }^{160}$ had been circulated. During the $11^{\text {th }}$ Meeting of States Parties it was decided to address the matter by a decision of the Meeting. ${ }^{161}$ This was the simplest way to reach a generally acceptable solution. Referring to the fact that the Commission had only adopted definitive guidelines for the preparation and making of submissions on 13 May 1999, the decision provides that for states, which had become a Party to the Convention before that date, the 10-year limit started to run on that date. The deferral of the time limit did not offer a solution that would allow for the indefinite shelving of the implementation of Article 76 in the Antarctic.

After the decision of the Meeting of States Parties to the LOSC the consultations between the claimant states were continued. The focus of the consultations now became attaining the coordination of their positions in approaching the Commission. A decision of the Meeting of States Parties to the LOSC dealing specifically with Antarctica for a number of reasons was not opportune. In the first place this would lead to the treatment of a question with implications for the legal regime of Antarctica outside the ATS, which is considered to be undesirable by the states participating therein. Secondly, especially Western states opposed attempts to accord the Meeting of States Parties a role in respect of substantive questions in respect of the Convention. ${ }^{162}$

From the start of the deliberations between the claimant states, it had been clear that certain states wanted to make a submission in respect of Antarctica, while other claimant states did not want to pursue that course. The claimant states were also divided on the question whether the submission of information to the CLCS would disturb the balance between the claimant states and the other states partici-

160. This agreement had been adopted in 1994 to adjust Part XI of the Convention to meet the demands of the industrialized states to bring about their adherence to the Convention (Agreement relating to the implementation of Part XI of the United Nations Convention on the Law of the Sea of 10 December 1982; 33 ILM p. 1309, adopted on 28 July 1994; entry into force 28 July 1996). Contrary to what the title of the agreement suggests it led to significant amendments to the Convention.

161. Decision regarding the Date of Commencement of the Ten-Year Period for Making Submissions to the Commission on the Limits of the Continental Shelf Set Out in article 4 of Annex II to the United Nations Convention on the Law of the Sea (SPLOS/72 of 29 May 2001).

162. See further T. Treves, 'The General Assembly and the Meeting of States Parties in the Implementation of the LOS Convention', in A.G. Oude Elferink, ed., Stability and Change in the Law of the Sea: The Role of the LOS Convention (Leiden, Martinus Nijhoff 2005) pp. 55-74, especially at pp. 6165 and 68-73; A.G. Oude Elferink, 'Reviewing the Implementation of the LOS Convention: the Role of the United Nations General Assembly and the Meeting of States Parties', in A.G. Oude Elferink and D.R. Rothwell, eds., Oceans Management in the 21st Century: Institutional Frameworks and Responses (Leiden, Martinus Nijhoff 2004) pp. 295-312 at pp. 306-310. 
pating in the ATS. Reportedly, in the consultations between the claimant states, the Russian Federation and the United States, specific reference was made to Article IV of the Antarctic Treaty in this connection. The claimant states also differed about whether or not to refer to the existence of disputes in making a submission to the CLCS. Australia has, for instance, taken the position that there is no dispute concerning the Australian Antarctic Territory. On the other hand, it was for instance for Argentina essential to be able to refer to the existence of a territorial dispute between Argentina and the United Kingdom. This dispute concerns both the Falkland Islands (Islas Malvinas), South Georgia, the South Sandwich Islands and the Antarctic continent. The sector of Antarctica claimed by both states overlaps to a large part. The Antarctic sector of Argentina and the United Kingdom moreover overlaps partially with the Antarctic sector claimed by Chile. Argentina takes the position that there is one dispute involving all these territories, a position which is not shared by the United Kingdom. Apparently, in Argentina's view a solution for the Antarctic continental shelf which would be tailored exclusively to deal with the issues raised by the interaction between the LOSC and the ATS might prejudice this position of Argentina.

At the end of 2004 the claimant states eventually reached a compromise for a common approach in respect of the continental shelf in Antarctica. This compromise employs the opportunities offered by Annex I to the Rules of Procedure of the Commission to deal with maritime and territorial disputes. The common approach envisaged two possibilities. A state could either submit information or refrain from doing so. In both cases the submitting state would employ common elements, which had been agreed upon in the consultations between the claimant states. If a state would opt to submit information, it would at the same time request the Commission not to take any action in respect of the submission concerning Antarctica. Because of the overlapping territorial claims of Argentina, Chile and the United Kingdom it was agreed that the common elements would be without prejudice to cases in which there existed a dispute over the delimitation of the continental shelf between states or other unresolved maritime or territorial disputes. For those cases, reference was made to paragraph 5 of Annex I to the Rules of Procedure of the Commission. Paragraph 5 envisages that the Commission in such cases will only consider a submission with the prior consent of all the parties to the dispute.

\subsection{The establishment of the outer limits of the continental shelf by individual states}

\subsubsection{The submissions by claimant states and the reactions of other states}

All Antarctic claimant states have by now submitted information to implement Article 76 in respect of their Antarctic territories. Argentina, Australia and Norway 
have submitted information on the outer limit of the continental shelf of their Antarctic territories. On the other hand, France, New Zealand and the United Kingdom have indicated, while making a submission for other territories, that for the moment they are refraining from making a submission concerning their continental shelf in Antarctica. ${ }^{163}$ Chile has not yet made a submission to the Commission, but has used the option to submit preliminary information. Chile's preliminary information, making reference to the common elements agreed upon between the claimant states, indicates that Chile will inform the Commission which option - making a submission or refraining from doing so - it will choose for the Chilean Antarctic Territory. ${ }^{164}$

The notes of France, New Zealand and the United Kingdom, in which they indicate that for the moment they are not making a submission in respect of the continental shelf in Antarctica, are largely identical. ${ }^{165}$ They recall the principles and objectives shared by the Antarctic Treaty and the LOSC and the importance of the ATS and the Convention working in harmony. Reference is also made to the circumstances of the area south of $60^{\circ} \mathrm{S}$, the special legal and political status of Antarctica under the Antarctic Treaty and that appurtenant to Antarctica there are areas of continental shelf whose extent still remains to be determined. It is furthermore observed that states have the possibility to either submit information to the CLCS, which will not be considered by the Commission, or to make a partial submission not including such areas of continental shelf. The notes indicate that in accordance with the Rules of Procedure of the Commission in the latter case a submission may be made at a later stage, notwithstanding the time limit for making submissions mentioned in Article 4 of Annex II to the LOSC and the decision on the time limit of the 11th Meeting of States Parties to the Convention. This language echoes paragraph 3 of Annex I to the Rules of Procedure of the CLCS. Paragraph 3 would seem to allow an indefinite deferral of a submission for (parts of) the outer limit of a coastal state. Paragraph 3 is intended to prevent prejudice to the delimitation of the continental shelf between coastal states. The broad formulation 'questions relating to the delimitation of boundaries' contained in paragraph 3

163. Note verbale No. 69 of February 2009 of the Permanent Mission of France to the United Nations to the Secretary-General of the United Nations; Note verbale NZ-CLCS-TPN-02 of 19 April 2006 of the Permanent Mission of New Zealand to the United Nations to the Secretary-General of the United Nations; Note verbale No. 168/08 of 9 May 2008 of the Permanent Mission of the United Kingdom to the United Nations to the Secretary-General of the United Nations.

164. Chile, Preliminary information indicative of the outer limits of the continental shelf and description of the status of preparation and intended date of making a submission to the Commission on the Limits of the Continental Shelf, pp. 16-17.

165. Differences exist in particular between the English text of the French note and the other two notes. These differences seem to be mostly explained by the fact that the former text was translated from French and is not based directly on the English text which contains the common elements agreed between the claimant states. 
makes it possible to argue that the entire continental shelf of Antarctica is covered by this provision.

The Netherlands and Japan reacted to the notes verbale of France, New Zealand and the United Kingdom accompanying their partial submissions. ${ }^{166}$ Both states stress the importance of maintaining harmony between the Antarctic Treaty and the LOSC and that they do not recognize the rights or claims of states over Antarctica and consequently also do not recognize the rights or claims of states over the maritime zones adjacent to Antarctica. In that light, the balance of rights and obligations in the Antarctic Treaty should not be affected by the intention expressed by France, New Zealand and the United Kingdom to submit information on the outer limits of the continental shelf adjacent to Antarctica.

Argentina, Australia and Norway have made a submission concerning the outer limit of their continental shelf in Antarctica. ${ }^{167}$ Australia and Norway, in making these submissions, have chosen similar wording to justify their approach as the three states which for the moment refrain from making such a submission. ${ }^{168}$ The main difference is that Australia and Norway indicate that they have opted to lodge a submission and that they request the Commission, in accordance with its Rules of Procedure, for the time being not to take any action in respect of the information related to the continental shelf of Antarctica.

Six states (Germany, India, Japan, the Netherlands, the Russian Federation and the United States) reacted to the submission of Australia in respect of Antarctica through notes addressed to the Secretary-General of the United Nations. ${ }^{169}$ Five of these six states: Japan, India, the Netherlands, the Russian Federation and the United

166. Note verbale SC/06/459 of 28 June 2006 of the Permanent Mission of Japan to the United Nations to the Secretary-General of the United Nations; Note verbale DJZ-IR 178/2006 of 19 December 2006 of the Permanent Mission of the Netherlands to the United Nations to the Secretary-General of the United Nations, infra p. 302; Note verbale No. NYV/2009/2184 of 28 August 2009 the Permanent Mission of the Netherlands to the United Nations to the Secretary-General of the United Nations; Note verbale SC/09/931 of 19 November 2009 of the Permanent Mission of Japan to the United Nations to the Secretary-General of the United Nations.

167. For the outer limits contained in these submissions see Figure II.

168. Note verbale No. 89/2004 of November 2004 of the Permanent Mission of Australia to the United Nations to the Secretary-General of the United Nations; Note verbale of 4 May 2009 of the Permanent Mission of Norway to the United Nations to the Secretary-General of the United Nations.

169. Note verbale No. 88/2005 of 5 April 2005 of the Permanent Mission of Germany to the United Nations to the Secretary-General of the United Nations; Note verbale NY/PM/443/1/98 of 5 July 2005 of the Permanent Mission of India to the United Nations to the Secretary-General of the United Nations; Note verbale SC/05/039 of 19 January 2005 of the Permanent Mission of Japan to the United Nations to the Secretary-General of the United Nations; Note verbale No. NYV/2005/690 of 31 March 2005 of the Permanent Mission of the Netherlands to the United Nations to the SecretaryGeneral of the United Nations; Note verbale No. 739/n of 9 December 2004 of the Permanent Mission of the Russian Federation to the United Nations to the Secretary-General of the United Nations; Diplomatic note POL 10-04 of 3 December 2004 of the Deputy Representative of the United States to the United Nations to the Secretary-General of the United Nations. 
States, have also reacted to the more recent submission of Norway. ${ }^{170}$ All these states indicate that they consider that the Commission should not consider the information submitted on the Antarctic continental shelf. In that connection reference is made, among others, to Article IV of the Antarctic Treaty. There are also differences between the notes. For instance, the Netherlands, before addressing the importance of Article IV, refers to the existence of an unresolved land dispute with respectively Australia and Norway. The differences between the reactions of the various states contribute to the impression that there was less coordination between them than between the claimant states.

On the basis of the request of Australia not to consider its submission in respect of Antarctica and the reactions of other states, the Commission decided that it would not consider this part of the Australian submission. ${ }^{171}$ It seems likely that the Commission will adopt the same approach in relation to the submission of Norway in respect of the Antarctic continent. ${ }^{172}$

Argentina took a different approach in making its submission on the continental shelf in Antarctica. The note of Argentina, like the notes of the other claimant states, refers to the importance of maintaining the harmony between the Antarctic Treaty and the LOSC and the circumstances in the area south of $60^{\circ} \mathrm{S}$ and the special legal and political status of Antarctica under the Antarctic Treaty. ${ }^{173}$ The note also refers to the Rules of Procedure of the Commission, but does not request the Commission not to consider the information submitted in respect of the continental shelf of Antarctica. It is not known why Argentina opted for this approach. Reportedly, other states considered that the Argentine approach was not in accordance with the agreement of the claimant states on a common approach. That view is reflected in the note of the United Kingdom reacting to the part of the Argentine submission dealing with Antarctica. ${ }^{174}$ The note observes, among other things:

170. Note verbale SC/09/389 of 19 November 2009 of the Permanent Mission of Japan to the United Nations to the Secretary-General of the United Nations; Note verbale No. NY/PM/443/1/2009 of 31 August 2009 of the Permanent Mission of India to the United Nations to the Secretary-General of the United Nations; Note verbale No. NYV/2009/2458 of 30 September 2009 of the Permanent Mission of the Netherlands to the United Nations to the Secretary-General of the United Nations; Note verbale No. 1682/n of 15 June 2009 of the Permanent Mission of the Russian Federation to the United Nations to the Secretary-General of the United Nations; Diplomatic note of 4 June 2009 of the Deputy Representative of the United States to the United Nations to the Secretary-General of the United Nations.

171. See Statement by the Chairman of the Commission on the Limits of the Continental Shelf on the progress of work in the Commission (CLCS/44 of 3 May 2005) para. 23.

172. Norway has not yet presented its submission to the Commission. The Commission will only take a decision on this matter after that presentation.

173. Note verbale N.U. 139/2009/600 of 21 April 2009 of the Permanent Mission of Argentina to the United Nations to the Secretary-General of the United Nations.

174. Note verbale No. 84/09 of 6 August 2009 of the Permanent Mission of the United Kingdom to the United Nations to the Secretary-General of the United Nations. 
'The United Kingdom noted in its Note 168/08 of 9 May 2008 that, as regards Antarctica, it was open to the States concerned to submit information pertaining to Antarctica to the Commission, which would not be examined by it for the time being, or to make a partial submission not including such areas of continental shelf.'

The United Kingdom further noted that, taking into account its observations and consistent with the approach taken by the United Kingdom and other Parties to the Antarctic Treaty, it expected that the Commission would not take any action on that part of the submission of Argentina for the time being. The other states which reacted to this part of the Argentine submission - Japan, India, the Netherlands, the Russian Federation and the United States - limited themselves to language which is similar to that in respect of the submissions of Australia and Norway in respect of the continental shelf of Antarctica. ${ }^{175}$

During the presentation of its submission to the Commission in August 2009, Argentina clarified its position. It submitted that through its note of 21 April 2009, Argentina took into account the circumstances of the area south of $60^{\circ} \mathrm{S}$ and that the Commission could not, for the time being, take any action with regard to the submission of Argentina related to the Antarctic territory. ${ }^{176}$ On the basis of this request and the reactions of other states, the Commission decided that it was not in a position to consider this part of the Argentine submission. ${ }^{177}$

The executive summary of the Argentine submission did distinguish between fixed points of the outer limit of the continental shelf of Antarctica and other parts of the continental shelf of Argentina. ${ }^{178}$ This should allow the Commission to split the submission into separate parts without difficulty.

\subsubsection{Substantive issues in the submissions on Antarctica by Argentina, Australia and Norway}

The submissions of Australia and Norway for their Antarctic territories take into account that the maritime boundaries with neighbouring territories have not yet

175. See Note verbale SC/09/391 of 19 November 2009 of the Permanent Mission of Japan to the United Nations to the Secretary-General of the United Nations; Note verbale No. NY/PM/443/1/2009 of 31 August 2009 of the Permanent Mission of India to the United Nations to the Secretary-General of the United Nations; Note verbale No. NYV/2009/2459 of 30 September 2009 of the Permanent Mission of the Netherlands to the United Nations to the Secretary-General of the United Nations; Note verbale No. 2282/N of 24 August 2009 of the Permanent Mission of the Russian Federation to the United Nations to the Secretary-General of the United Nations; Diplomatic note of 19 August 2009 of the Permanent Mission of the United States to the United Nations to the Secretary-General of the United Nations.

176. Statement by the Chairman of the Commission on the Limits of the Continental Shelf on the progress of work in the Commission (CLCS/64 of 1 October 2009), para. 73.

177. Ibid., para. 77.

178. Outer limits of the Continental Shelf; Argentine Submission, Executive Summary, p. 14. 
been established. Apart from a lateral boundary with Norway, Australia also shares lateral boundaries with France and New Zealand. The executive summary of Australia's submission does not refer to a boundary with New Zealand. This may be explained by the fact that New Zealand in the area concerned does not have a continental shelf beyond 200 nautical miles. ${ }^{179}$ In respect of France and Norway, Australia's executive summary observes that both states have indicated that they have no objection to the inclusion of the area of overlapping claims in the submission of Australia, without prejudice to the eventual delimitation of their bilateral boundaries. ${ }^{180}$ The figures of the continental shelf of the Australian Antarctic Territory included in the executive summary distinguish between the outer limit in areas of potential delimitation and other parts of the outer limit of the continental shelf. A similar distinction is made for the 200-nautical-mile limit. ${ }^{181}$ In the case of France, the area of potential delimitation seems to be identified by the meridians which also form the boundary between the Australian and French territories. In the case of Norway, an analogous point seems to have been adopted. The last part of the outer limit in this area of potential overlap seems to be an equidistance line between both territories, which runs from the outer limit of the continental shelf to the 200-nautical-mile limit. ${ }^{182}$ The executive summary observes that the approach which has been followed to identify the areas of potential delimitation 'does not reflect any view with regard to the merits of any delimitation methodology'. ${ }^{183}$ Unless a meridian has been accepted as a boundary by the common practice of neighbouring states, international law does not accord any particular role to these lines in the delimitation of maritime boundaries. ${ }^{184}$ Equidistance would seem to result in a solution in accordance with the substantive rules concerning delimitation for all these boundaries. ${ }^{185}$

179. The first fixed point of the outer limit of the continental shelf beyond 200 nautical miles of the Australian Antarctic Territory is located on the 200-nautical-mile limit (Continental Shelf Submission of Australia, Executive Summary, Annex I, p. 6). This point seems to be located at the point at which the 200-nautical-mile limit of Australia intersects the 200-nautical-mile limit of New Zealand.

180. Continental Shelf Submission of Australia, Executive Summary, p. 11.

181. See ibid., figures ANT-MAP-ES-1 and ANT-MAP-ES-2. The table listing the fixed points of the outer limits of the continental shelf contained in Annex 1 to the executive summary does not make a similar distinction (see ibid., Annex I, pp. 5-11).

182. See ibid., figures ANT-MAP-ES-1 and ANT-MAP-ES-2.

183. Ibid., p. 41.

184. See also A.G. Oude Elferink, The Law of Maritime Delimitation: A case study of the Russian Federation (Dordrecht, Martinus Nijhoff 1994) pp. 222-223.

185. For further information on the delimitation of maritime zones in Antarctica see S.B. Kaye, 'Antarctic Maritime Delimitations', in A.G. Oude Elferink and D.R. Rothwell, eds., The Law of the Sea and Polar Maritime Delimitation and Jurisdiction (The Hague, Martinus Nijhoff 2001) pp. 157178. 
The submission of Australia includes the entire outer limit of the continental shelf of France's Antarctic claim. In that sense there would be no practical need for France to make its own submission to the Commission in the future. ${ }^{186}$

The executive summary of the submission of Norway also refers to the existence of an agreement between Norway and its neighbours on outstanding delimitations, providing that the submission is without prejudice to the eventual bilateral delimitations. ${ }^{187}$ Apart from Australia, this concerns the United Kingdom. It is remarkable that reference is also made to the United Kingdom, because the outer limit of the continental shelf submitted by Norway is located in an area which is hundreds of nautical miles from the British territory in Antarctica. ${ }^{188}$ The executive summary of Norway does indicate a part of the equidistance line with the United Kingdom within the 200-nautical-mile limit and indicates the 200-nautical-mile limit beyond that line. ${ }^{189}$ This part of the 200 -nautical-mile limit is not relevant for the delineation of the outer limit of the continental shelf beyond 200 nautical miles. There may be a number of explanations for this approach. It may be intended to support the view of the United Kingdom in respect of the overlap of the latter's claim with Argentina. As a matter of fact, the executive summary of Norway does not refer to Argentina as a neighbouring state, although the lateral limit that Argentina claims for its maritime zones does in part extend beyond the equidistance line between Norway and the United Kingdom. ${ }^{190}$ Secondly, it may be intended to emphasize that Norway considers that the lateral boundaries of its maritime zones in Antarctica should not be delimited by meridians. ${ }^{191}$

In the case of Norway and Australia there is an overlap of the continental shelf beyond 200 nautical miles. Contrary to Australia, Norway does not use the meridian which bounds the territories of the two states to determine the area of potential delimitation. It seems likely that this approach is explained by the fact that this boundary runs along a meridian and the use of this line in Antarctica would form an unwelcome precedent for the delimitation between Norway and the Russian Federation, in which case the latter submits that the boundary should be a sector line running along a meridian. ${ }^{192}$ The Norwegian executive summary identifies an

186. France might be able to submit an outer limit which is slightly seaward from the outer limit submitted by Australia. In this area the constraint of 350 nautical miles is relevant, which in part may be slightly more seaward for France.

187. Continental Shelf Submission of Norway in respect of Bouvetøya and Dronning Maud Land; Executive Summary, p. 11.

188. See ibid., Figure 7.

189. See ibid.

190. The equidistance line depicted in the executive summary of Norway does not extend to the 200-nautical-mile limit but stops before it reaches the lateral limit of Argentina's maritime zones.

191. See further infra.

192. See also supra section 4.2 . 
equidistance line which runs to the outer limit of the continental shelf beyond 200 nautical miles. ${ }^{193}$ The last fixed outer limit point to the west of the equidistance line (SED 17) is based on information which has been provided by Australia and the outer limit up to the next fixed point is indicated as tentative. ${ }^{194}$

Argentina in the executive summary of its submission does not refer explicitly to boundaries with neighbouring states. Both the western and eastern limit of the Argentine Antarctic territory is located in an area that is also claimed by another state (respectively Chile and the United Kingdom). In both cases Argentina employs the meridian which defines the extent of its Antarctic territory as the lateral limit of the 200-nautical-mile zone of Argentina. ${ }^{195}$ An outer limit of the continental shelf beyond 200 nautical miles is only present at the eastern limit of the Argentine sector. This outer limit line stops at the seaward extension of this eastern limit and the outer limit line subsequently follows the lateral limit up to its intersection with the 200-nautical-mile limit of Argentina. This part of the line, located between the fixed points RA-6333 and RA-6336, is identified as 'international limit'. ${ }^{196}$ In defining this outer limit beyond 200 nautical miles, Argentina has not taken into account the 200-nautical-mile limit generated by the partly overlapping territorial claim of the United Kingdom or that of Norway. As can be appreciated from Figure II, at p. 181, fixed point RA-6336, which is on the 200-nautical-mile limit of Argentina, is within 200 nautical miles of the baselines of these other territories.

Apart from the delimitation with neighbouring states, the submissions of Argentina, Australia and Norway in respect of Antarctica also have another aspect of interest to the law of the sea. Reference was already made to the fact that the submissions also contain information on the 200-nautical-mile limit of these states. The constraint line at 350 nautical miles contained in Article 76 of the Convention, which is relevant to parts of all three submissions, is also measured from the baseline of the territorial sea. Article 5 of the Convention provides that the normal baseline is the low-water line along the coast as marked on large-scale charts officially recognized by the coastal state. In Antarctica it is in certain areas not possible to determine the low-water line along the coast because of ice shelves. An ice shelf is the part of a glacier which flows down into the sea. At its seaward edge a glacier may still be hundreds of meters high. The question of how to deal with ice shelves in connection with the determination of the low-water line has been extensively discussed in the legal literature. ${ }^{197}$ In indicating the limits of ice on nautical charts

193. Continental Shelf Submission of Norway in respect of Bouvetøya and Dronning Maud Land; Executive Summary, Figure 7.

194. See ibid., Figure 7 and p. 45. For the location of these points see also Figure II.

195. See for instance, Outer limits of the Continental Shelf; Argentine Submission, Executive Summary, Figure 6.

196. Ibid, p. 201.

197. For a recent article see S.B. Kaye, 'Territorial sea baselines along ice-covered coasts: International practice and limits of the Law of the Sea, 35 Ocean Development and International Law (2004) pp. 75-102. 
a distinction is made between a limit formed by shelf ice and by pack ice (sea ice). ${ }^{198}$ It seems that states, in making a submission to the Commission, have employed the latter limit to determine the baseline. Article 5 of the Convention does not indicate explicitly whether the use of the edge of permanent ice is a valid method to determine the low-water line. An argument in favour of that approach would be that the limit of permanent ice on nautical charts has a similar function for navigation as the low-water line. For Australia the use of the edge of permanent ice as the baseline in general has little impact at the 200 or 350-nautical-mile limits. In the case of Argentina, this impact is much bigger. Norway reportedly where possible used the low-water line along the coast. In cases in which that would have been inappropriate or impractical, conservative estimates of permanent ice have been made.

\subsubsection{The continental shelf of subantarctic islands and the Antarctic Treaty ${ }^{199}$}

The submissions of coastal states to the Commission indicate that in three cases the outer limits of the continental shelf of subantarctic islands in part extend into the Antarctic Treaty area. This concerns the submission of Australia in respect of Heard Island and the McDonald Islands on the one hand and Macquarie Island on the other,${ }^{200}$ and of the United Kingdom in respect of South Georgia and the South Sandwich Islands. The submission of information in respect of that part of the outer limits of the continental shelf of these islands is in accordance with the general approach in respect of these islands under the ATS. It can furthermore be noted that no state, as far as is known, has made observations in respect of this aspect of these submissions of Australia and the United Kingdom. ${ }^{201}$ The consideration of these submissions by the Commission nonetheless raises questions concerning the interaction with the ATS.

In the case of Australia, the outer limit of the continental shelf of Heard Island and the McDonald Islands extends to the 200-nautical-mile limit of the Antarctic continent. ${ }^{202}$ The United Kingdom has taken the same approach in its submission

198. See International Hydrographic Organization, Status of Hydrographic Surveying and Nautical Charting in Antarctica (Special Publication No. 59; updated December 2002; International Hydrographic Bureau, Monaco), p. I-27.

199. For a discussion of this topic see also A.D. Hemmings and T. Stephens, Reconciling Regional and Global Dispensations: The Implications of Subantarctic Extended Continental Shelf Penetration of the Antarctic Treaty Area (Sydney Law School, Legal Studies Research Paper No. 09/68 July 2009).

200. Macquarie Island is not further considered here as its continental shelf as far as can be ascertained does not overlap with the continental shelf of territory south of $60^{\circ} \mathrm{S}$.

201. None of the notes of states lodged with the Secretary-General in reaction to the publication of the executive summary of these submissions raises this issue.

202. As is suggested by the numbering of the fixed outer limit points of the continental shelf of Heard Island and the McDonald Islands contained in Australia's submission, Australia has also deter- 
in respect of South Georgia and the South Sandwich Islands. This approach of Australia and the United Kingdom is in accordance with the practice of a large number of states, which in making their submission to the Commission do not extend their outer limit landward of the 200-nautical-mile limit of neighbouring states. That approach may be explained by reasons of convenience or legal considerations. ${ }^{203}$

The continental shelf beyond 200 nautical miles of all of these islands also overlaps with the continental shelf beyond 200 nautical miles of Antarctica. In the case of Australia this is indicated by a comparison of the outer limit of the continental shelf of Heard Island and the McDonald Islands and the outer limit of the continental shelf of the Australian Antarctic Territory contained in Australia's submission. ${ }^{204}$ In the case of the United Kingdom this appears from a comparison of the submission of the United Kingdom to that of Argentina. The continental shelf beyond 200 nautical miles of the Argentine Antarctic territory overlaps with that of the islands. These overlaps raise the question whether the establishment of the outer limits of these subantarctic islands in accordance with Article 76 might be inconsistent with the obligations of states under the Antarctic Treaty.

In its recommendations to Australia, the Commission in respect of the continental shelf of Heard Island and the McDonald Islands for the area south of $60^{\circ} \mathrm{S}$ accepted the fixed outer limit points submitted by Australia, except for the two points (732a and 960a), which are located on the 200-nautical-mile limit of the Australian Antarctic Territory. ${ }^{205}$ The Commission's explanation for not accepting these two points is that its recommendations 'are without prejudice to matters related to other treaties'. The Commission further indicated that its recommenda-

mined the outer limit of the continental shelf of the islands within 200 nautical miles of Antarctica. Points with numbers between 732a and 960a - the numbers of the fixed points, which are located on the 200-nautical-mile limit of Antarctica - are not included in the submission. The summary of the recommendations of the Commission to Australia confirms that these points had indeed been established by Australia (see Summary of the Recommendations of the Commission on the Limits of the Continental Shelf (CLCS) with regard to the submission made by Australia on 15 November 2004; Recommendations adopted by the Commission on 9 April 2008, p. 12, Figure C.2).

203. States may either consider that there is no obligation to submit information for areas within 200 nautical miles of another state or that the exclusive economic zone of one state takes precedence over the continental shelf beyond 200 nautical miles of another state. A number of states, including Australia, do not support the latter view. Australia has also refrained from making a submission for two areas beyond 200 nautical miles that are within 200 nautical miles of respectively East Timor and Indonesia, but which Australia considers to be part of its continental shelf. For a further discussion of this issue in general and Australia's approach see A. Serdy, 'Is there a 400-mile rule in UNCLOS Article 76(8)?', 57 International and Comparative Law Quarterly (2008) pp. 941-954.

204. See also A. Serdy, 'Towards Certainty of Seabed Jurisdiction beyond 200 Nautical Miles from the Territorial Sea Baseline: Australia's Submission to the Commission on the Limits of the Continental Shelf', 36 Ocean Development and International Law (2005) pp. 201-217 at p. 210.

205. For the location of these points see Figure II. 
tions only deal with issues related to Article 76 of and Annex II to the Convention. ${ }^{206}$ The Commission recommended Australia to proceed to establish the outer limits in accordance with its recommendations.

The Commission's approach to fixed points 732a and 960a might seem to be somewhat puzzling. ${ }^{207}$ These points do no extend the outer limit of the continental shelf into the 200-nautical-mile zone of the Antarctic continent and, as such, they would not affect that maritime zone. What is more, as was observed above, fixed points $732 \mathrm{a}$ and $960 \mathrm{a}$ are not the only points which overlap with the maritime zones of Antarctica. Fixed points 665 to 732 of the outer limit of the continental shelf of Heard Island and the McDonald Islands are within the outer limit of the continental shelf beyond 200 nautical miles of the continental shelf of the Australian Antarctic Territory submitted by Australia. ${ }^{208}$ This raises the question why the Commission has made this distinction between points $732 \mathrm{a}$ and $960 \mathrm{a}$ and points 665 to 732. If defining points on the 200-nautical-mile limit was considered to be prejudicial to other treaties, this must a fortiori be the case for points lying inside the continental shelf of Antarctica. The approach of the Commission seems to be explained by the fact that it was not in a position to consider the submission of Australia in respect of the outer limit of the continental shelf of Antarctica and, formally speaking, was not aware of the location of the outer limits as submitted by Australia for that area. On the other hand, it could be argued that Australia was under an obligation to bring the overlap between the two continental shelves to the attention of the Commission, as this seems to be a dispute in the sense of Annex I to the Rules of Procedure related to the submission in respect of the continental shelf of Heard Island and the McDonald Islands. ${ }^{209}$

Would the establishment of the outer limits of the continental shelf of Heard Island and the McDonald Islands by Australia in accordance with Article 76(8) of the LOSC, to the extent that they overlap with the continental shelf of Antarctica, be incompatible with the obligations of Australia under the ATS? This matter is not explicitly addressed in the Antarctic Treaty. It could be argued that the establishment of such outer limits would be contrary to the object and purpose of the Antarctic Treaty, which, as is indicated by the preamble, is inter alia intended to maintain the status quo in the Antarctic Treaty area and maintain it for mankind. It might be

206. Summary of the Recommendations of the Commission on the Limits of the Continental Shelf (CLCS) with regard to the submission made by Australia on 15 November 2004; Recommendations adopted by the Commission on 9 April 2008, paras. 5 en 53 .

207. For another criticism of this aspect of the Commission's recommendations to Australia see Serdy, supra $\mathrm{n} .153$.

208. See also Serdy, supra n. 204, at p. 210.

209. See also infra on the consequences of the overlap between the two areas of continental shelf for establishing the outer limits for Heard Island and the McDonald Islands on the basis of the recommendations of the Commission. 
argued that this view does not find support in later practice in respect of subantarctic islands in the framework of the ATS. As was discussed above, in connection with the adoption of CRAMRA it was explicitly acknowledged that this Convention did not apply to the continental shelf of the subantarctic islands. However, that interpretative statement does not address the delimitation between those shelf areas and that of the Antarctic continent. That consideration would also seem to be relevant to the establishment of the outer limits of the continental shelf of Heard Island and the McDonald Islands on the basis of the recommendations of the Commission. Article 76(10) of the LOSC provides that the provisions of Article 76 are without prejudice to the delimitation of the continental shelf between neighbouring states. This implies, among other things, that Article 76(8) in principle does not lead to final and binding limits in an area that is the subject of an overlapping area of another state's continental shelf. In view of the fact that the question of sovereignty over Antarctica is suspended by the Antarctic Treaty, it would be impossible for Australia to argue that its case is similar to that of Norway as regards the internal delimitation involving Bear Island. ${ }^{210}$ In other words, Australia is not in a position to unilaterally establish an internal administrative boundary between Heard Island and the McDonald Islands and the Australian Antarctic Territory that ipso facto would be binding on other states.

The preceding analysis also applies to the continental shelf of South Georgia and the South Sandwich Islands. In view of the territorial dispute between the United Kingdom and Argentina it is unlikely that the Commission in this case in the foreseeable future will adopt recommendations which will allow the United Kingdom to establish permanent limits for this area. Argentina has indicated that in view of the dispute it considers that the Commission should not consider the submission and that it would object to the Commission making recommendations. ${ }^{211}$

\section{CONCLUSIONS}

The question in the title of this article is certainly not answered by the first part of the suggested answer. International law plays an important role in the determination of the outer limits of the continental shelf. This concerns both the substantive and procedural rules. As far as can be ascertained all states with a continental shelf beyond 200 nautical miles which were required to make a submission to the CLCS have done so. States for which the time limit for making a submission has not yet lapsed are gathering and processing the required data. This also applies to the polar

210. See supra $\mathrm{n} .129$ and the accompanying text.

211. Letter of 20 August 2009 of the Permanent Representative of Argentina to the United Nations to the Secretary-General of the United Nations. 
regions. There is no question of an unregulated race to the North Pole. At the same time, Article 76 is not 'black-letter law'. The implementation of Article 76 raises numerous intricate questions. Again, this is also the case for the polar regions. This concerns, among others, Article 76(6), which makes a distinction between submarine ridges and submarine elevations. Along submarine elevations the outer limit of the continental shelf may be hundreds of miles seaward of the outer limit along submarine ridges. The difficulties involved in interpreting and applying Article 76(6) can be seen as a fundamental flaw in Article 76. During UNCLOS III a number of compromises resulted in the Delphic formulation of Article 76(6). Furthermore, the further specification of this rule is likely to be beyond the purview of judicial review. The implementation of Article 76(6) in important measure is linked to scientific interpretations and the evaluation of scientific and technical information. This first of all is a task for the CLCS. If questions in respect of Article 76(6) were to be submitted to third party dispute settlement, it is highly unlikely that a judge or arbitrator will evaluate the work of the Commission. It is moreover questionable whether the adoption of general guidelines for the application of Article 76(6) would make sense, to the extent that this is possible.

This separation of the Article 76 procedure from third party dispute settlement would seem to make it essential that third states are assured that the Commission will not stray beyond its mandate and will refrain from legal interpretations of the Convention. The practice of the Commission indicates that it is still trying to come to terms with this difficult task. A number of factors may explain the Commission's difficulties. The procedure involving the Commission in certain respects is innovatory and cannot build on the experience of other treaty bodies. Secondly, the Commission to a certain extent depends on the input it receives from the States Parties to the Convention. For instance, the Commission was probably not informed of the potential overlap between the continental shelf beyond 200 nautical miles of Heard Island and the McDonald Islands and that of the Australian Antarctic Territory, which has led to an apparent inconsistency in its recommendations to Australia on the outer limits of the former.

There are indications that the Commission will act with reserve in cases in which the legal interpretation of provisions of the Convention are concerned. Whether this is also the case for Article 76 remains to be seen. First, the Commission's mandate is focused on Article 76 and too cautious an approach might lead to a complete standstill. Secondly, the practice of the Commission discussed in this article shows that there is scope to frame questions concerning the application of Article 76 in terms of the assessment of scientific data instead of legal interpretation. There is a risk that this approach leads to different outcomes than those that were envisaged when Article 76 was negotiated, as is witnessed by the discussion of Article 76(6). However, that risk may be inherent in the creation of treaty bodies. Moreover, States Parties to the Convention have not been mere bystanders in 
the developing practice of the Commission, but have had and continue to have numerous possibilities to make their views known.

There are both differences and similarities between the polar regions in respect of Article 76 of the Convention. The most important similarity is that this concerns a process in which individual coastal states take the lead. The most important possibility for other states to influence the process is at the moment the executive summary of a submission is made public. Other states at that moment have the possibility to point to the existence of land or maritime disputes in the sense of Annex I to the Rules of Procedure of the Commission. Among others, the case of Antarctica demonstrates that Annex I can be used to address a wide range of issues. At the same time the precise scope of application of Annex I remains unclear. Practice in respect of Annex I seems to indicate that if the submitting state and other states disagree about whether a submission should be considered or not, the Commission tends to lean towards an approach that only takes into account observations from neighbouring states and in cases concerning other matters will consider a submission and will indicate that it is without prejudice to other parts of the Convention or other treaties. This allows the adoption of recommendations on the basis of which a coastal state can adopt outer limit lines. At the same time, the existence of disputes over matters related to such outer limits indicates that they cannot, in principle, be considered to be final and binding in the sense of Article 76(8) of the Convention. This problem is inherent in the procedure set up by the Convention, which implies that legal aspects related to the implementation of Article 76 are not scrutinized by the Commission.

The major difference between the polar regions is the existence of the ATS in Antarctica. The relationship between the obligations of states under the ATS and the LOSC required a careful approach to the implementation of Article 76 of the latter. The content of that approach has been primarily shaped by the Antarctic claimant states. The influence of other states has been limited. The amount of coordination between claimant states - notwithstanding the major differences between their positions - also seems to go beyond the coordination between non-claimant states. It seems, furthermore, that the approach adopted by the claimant states, which is in line with the constructive ambiguity of the ATS, has reinforced their position from a political perspective. ${ }^{212}$ Certain claimant states have made a considerable effort to implement Article 76 of the Convention. This can be expected to be an argument which will be used in the future if need be. The argument that the request of claimant states to the CLCS to refrain from considering their submission has weakened their position has also been advanced. ${ }^{213}$ If anything, these contrasting views are testimony to the legal and political complexities of this matter.

212. Cf., Koivurova, supra n. 58, at p. 495.

213. Serdy, supra n. 153. 
It also seems that claimant states have used their submission to the CLCS to reaffirm their views on other aspects of the law of the sea related to their claims, such as baselines and bilateral boundaries.

Another interesting development in Antarctica concerns the subantarctic islands. The Commission recommended Australia to proceed with the establishment of outer limits for the continental shelf of Heard Island and the McDonald Islands. It is however submitted that these outer limits are in principle not final and binding to the extent that they overlap with the continental shelf of Antarctica. This is explained by the existence of the Antarctic Treaty and Article 76(10) of the LOSC.

In the Arctic a considerable time can be expected to pass before the outer limit of the continental shelf will have finally been established. Norway is in a position to establish the outer limit of its continental shelf beyond 200 nautical miles in the area to the north of Svalbard. The outer limit of Norway's continental shelf in the Barents Sea depends on an agreement on a bilateral boundary with the Russian Federation. One of the most significant legal questions in respect of the continental shelf in this area is whether Norway can unilaterally establish the internal administrative limits between the continental shelf of the Norwegian mainland and Svalbard. The precedent of the 200-nautical-mile zone suggests that other states have not objected to the principle which is involved. The practical implications would be much greater in the case of the continental shelf, as is also witnessed by Norway's legislation on oil activities which provides that it applies to the entire continental shelf and only excludes the area landward of the outer limit of the territorial sea of the archipelago. Under international law that approach would at least seem difficult for the area which in accordance with Article 76 is only part of the continental shelf of Svalbard. That may however only concern a limited part of the continental shelf beyond 200 nautical miles.

Other Arctic states will first have to finalize the procedure involving the Commission. In view of the present workload of the Commission this is likely to take a long time, although it remains to be seen how the Commission will handle the queuing of a new or revised submission by the Russian Federation. For all these Arctic states the interpretation of Article 76(6) will play a role in the determination of the outer limit of their continental shelf. If Canada, Denmark and the Russian Federation will be able to convince the Commission that the Alpha-Mendeleyev Ridge and the Lomonosov Ridge are submarine elevations and not submarine ridges and their outer limit will consequently extend beyond 350 nautical miles the three states will have to agree among themselves on the delimitation of the area around the geographical North Pole. In view of the politico-psychological significance of this point, and the fact that the North Pole would likely be part of the continental shelf of Denmark if the substantive rules of maritime delimitation law were to be applied, this, in all likelihood, will be a difficult exercise. The delimitation involving Norway and the Russian Federation is similar in a certain sense: not too com- 
plicated from a legal perspective but involving comparable politico-psychological factors. The extent of the continental shelf in Canada's western Arctic sector might contribute to a reconsideration of Canada's position on the bilateral boundary with the US in the Beaufort Sea within 200 nautical miles.

The implementation of Article 76 in the polar regions is largely similar to other regions of the world. Article 76 contains an arrangement of considerable legal complexity, which often has to be applied in a complex legal and politico-geographical context. The successful completion of this process would be an important contribution to the stability of the LOSC and international law generally.

\section{ABSTRACT}

The polar regions stand apart from other areas of the globe because of their severe climate and remoteness. Those conditions have also impacted on the development of the legal regime of the polar regions and led to questions concerning the applicability of general public international law to these regions. The present article investigates this interaction from the perspective of one specific issue: the establishment of the outer limits of the continental shelf in accordance with Article 76 of the United Nations Convention on the law of the sea. Article 76 at present is being implemented worldwide by coastal States and the polar regions are no exception. The present analysis indicates that the implementation of Article 76 in the polar regions is largely similar to other regions of the world. Article 76 contains an arrangement of considerable legal complexity, which often has to be applied in a complex legal and politico-geographical context. The major differences with other regions are no doubt presented by Antarctica, in which case at least for the moment the process of implementing Article 76 will not be finalized. 


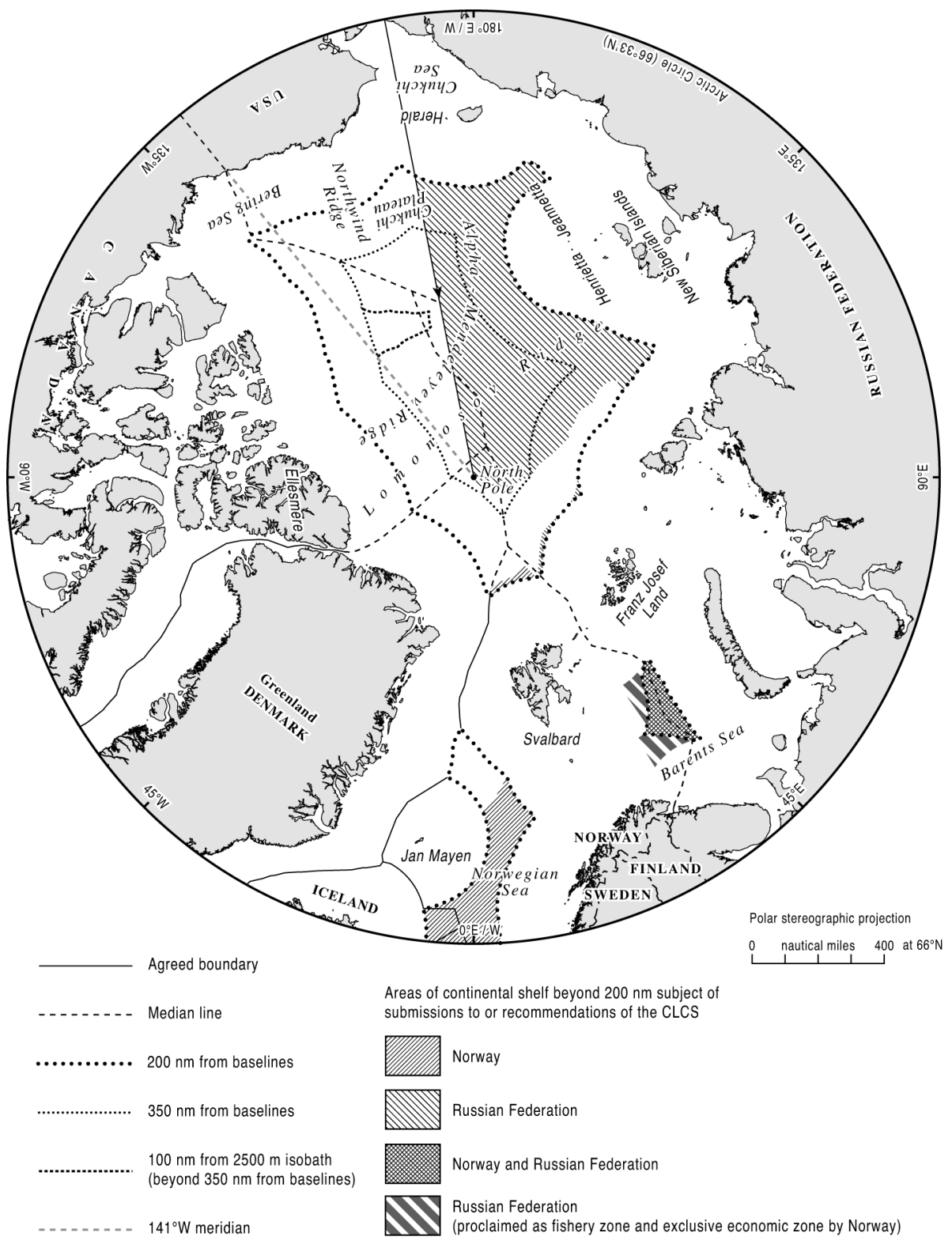

Fig. I: Current state of implementation of article 76 in the Arctic. 


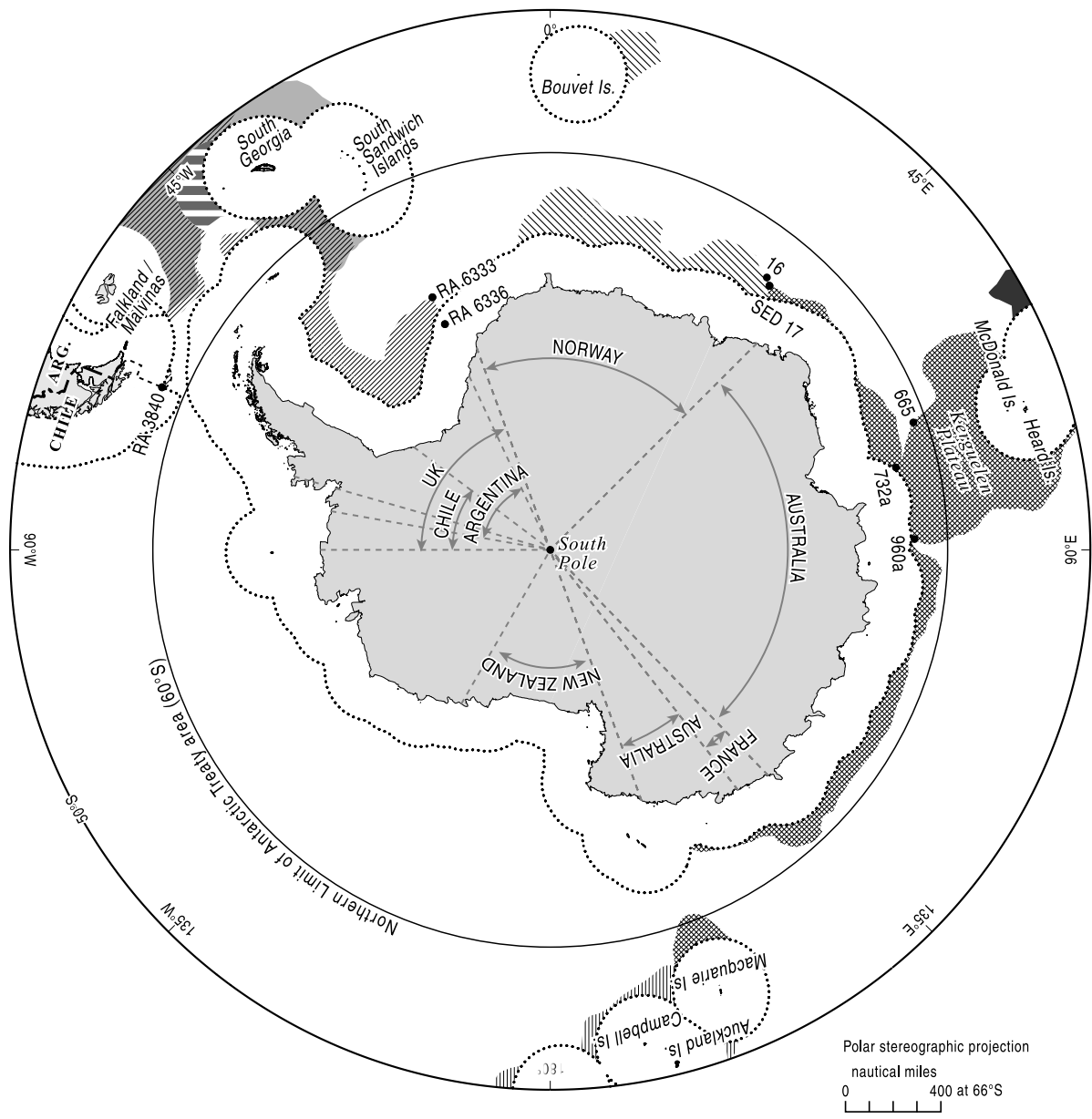

Areas of continental shelf beyond $200 \mathrm{~nm}$ subject of submissions to or recommendations by the CLCS

$200 \mathrm{~nm}$ from baselines

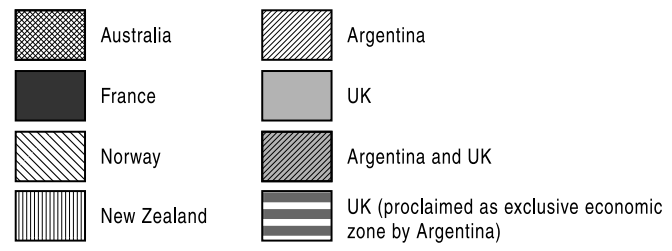

Fig. II: Current state of implementation of article 76 in Antarctica. 